\title{
Predatory Pricing: A Strategic and Welfare Analysis*
}

\author{
Oliver E. Williamson ${ }^{\dagger}$
}

Until recently predatory pricing ${ }^{1}$ has been a relatively vague concept in antitrust law. This may be because emotive terms, such as predatory pricing, do not invite and sometimes defy analysis. But the lack of precision may also reflect a sense that the familiar tools of static economic analysis are ill-suited to cope with the issues posed by predatory pricing. As developed in this article, predatory pricing involves strategic behavior in which intertemporal considerations are central. Static economic models that fail to capture these attributes miss crucial features of the predatory pricing issue.

Recently a remarkable degree of consensus in favor of cost-based rules has appeared in court opinions dealing with predatory pricing. ${ }^{2}$ This judicial consensus may be a response to a series of articles addressed to predatory pricing issues, the most significant being commentary by Edward Cooper and studies by Richard Posner and by

* Research on this paper was supported by the Center for the Study of Organizational Innovation at the University of Pennsylvania and by a grant from the National Science Foundation. Work on the final version of the paper was completed while I was a Fellow at the Center for Advanced Study in the Behavioral Sciences, Stanford, California. Comments by Paul Joskow, Richard Posner, and Donald Turner on earlier versions of the paper are gratefully acknowledged, as are comments by Industrial Organization Workshop participants at the University of Pennsylvania and the University of Chicago. Econ. omists and lawyers in the Antitrust Division of the United States Department of Justice also commented usefully on an oral presentation of the penultimate version of this paper.

$\dagger$ Professor of Economics, Law, and Public Policy, University of Pennsylvania.

1. Section 2 of the Sherman Act, 15 U.S.C. $\$ 2$ (Supp. V 1975), proscribes predatory pricing as an act of monopolization or an attempt to monopolize. See, e.g., United States v. American Tobacco Co., 221 U.S. 106, 182 (1911); Standard Oil Co. v. United States, 221 U.S. 1, 43 (1910). Clayton Act $\$ 2$, as amended by the Robinson-Patman Act, 15 U.S.C. $\$ 13(1970)$, and Robinson-Patman Act $\$ 3$, id. $\$ 13 a$, also proscribe predatory pricing. The issues are the same under all three provisions.

2. See Pacific Eng'r \& Prod. Co. v. Kerr-McGee Corp.; 551 F.2d 790, 797 (10th Cir. 1977), petition for cert. filed, 46 U.S.L.W. 3141 (U.S. Sept. 19, 1977); Hanson v. Shell Oil Co., 541 F.2d 1352, 1358 (9th Cir. 1976), cert. denied, 97 S. Ct. 813 (1977); National Ass'n of Regulatory Util. Comm'rs v. FCC, 525 F.2d 630, 637-38 \& n.34 (D.C. Cir. 1976), cert. denied, 425 U.S. 992 (1976); International Air Indus. v. American Excelsior Co., 517 F.2d 714, 723-25 (5th Cir. 1975), cert. denied, 424 U.S. 943 (1976); Weber v. Wynne, 5 TrADE. Rec. Rep. (CCH) (1977-1 Trade Cas.) If 61,315 (D.N.J. 19'7 7 ); Inter City Oil Co. v. Murphy Oil Co., [1976-1] Trade Cas. đ 60,948, at 69,176 (D. Minn. 1976). 
Philip Areeda and Donald Turner. $^{3}$ Posner and Areeda-Turner brought the tools of static economic analysis to bear on the problem and produced a set of cost-based tests for evaluating allegations of predatory pricing. ${ }^{*}$ The Areeda-Turner rules have not only been embraced by the courts, but have also influenced a Justice Department decision to withdraw a suit in progress. ${ }^{5}$

Though the Areeda-Turner and Posner studies are important contributions, I nonetheless have serious reservations about them. Both studies fail to account for two major intertemporal attributes of predatory pricing. First, although static welfare economics may be adequate to evaluate a market where there is a shift from one steady level of supplying a good or service to a second steady level, the same model can be misleading if the shift in question is temporary or contingent and arguably has the purpose of deterring future rivalry. Second, and perhaps somewhat more subtle, firms have incentives to adapt to rules of law. These adaptations must expressly be taken into account in an evaluation of the economic consequences of a legal rule. When allowance is made for these dynamic effects, the Areeda-Turner rules can be shown to have inferior efficiency properties as compared with the alternative set of rules proposed in this article. In addition, the alternative rules are more easily enforced and explicitly recognize the differences between competition among a group of established oligopolists and the rivalry that occurs between a dominant firm and new entrants.

Part I begins by providing background on predatory pricing and gives reasons to be skeptical about the properties of the rules favored by Areeda and Turner. The efficiency benefits of their marginal cost pricing rules are questioned on the ground that they may not yield the immediate social welfare gains that Areeda and Turner attribute to

3. R. Posner, ANtitrust Law: Ax Economic Perspective 184-96 (1976); Arecda \& Turner, Predatory Pricing and Related Practices under Section 2 of the Sherman Act, 88 HARv. L. REv. 697 (1975); Cooper, Altempts and Monopolization: A Mildly Expansionary Answer to the Prophylactic Riddle of Section Two, 72 Mich. L. Rev. 373, 435-40 (1974).

4. Important differences should, however, be noted. Areeda and Turner favor a shortrun marginal cost rule while Posner proposes long-run marginal cost as the test criterion. Compare R. Pos. ER, supra note 3, at 191-93 with Areeda \& Turner, supra note 3, at 732-33.

5. Former Assistant Attorney Gencral Thomas E. Kauper explained the Antitust Division's decision to dismiss the Government's antitrust case against two major tire companies partly on the ground that "[i]t is now clear that any theory of Section 2 liability upon which we could rely in these cases cannot rest upon traditional predatory conduct, because we cannot demonstrate that the defendant in either case set prices below marginal or average variable costs." Memorandum for Attorney General Edward Levi, February 23, 1976, reprinted in 5 TRADE REc. REP. (CCH) If 50,259 (1976) (in relation to United States v. Firestone Tire and Rubber Co., Civ. No. C-73-836, and United States v. Goodyear Tire \& Rubber Co., Civ. No. C-73-835 (N.D. Ohio 1976)). 
them and, more importantly, because their proposed rules make no allowance for strategic behavior by dominant firms. ${ }^{6}$ An attempt is then made to remedy the latter shortcoming by developing a model in which the strategic motivations of firms engaging in predatory behavior are expressly acknowledged. The model focuses on predatory pricing to deter entry into the dominant firm's market, and investigates the effects of three alternative predatory pricing rules on prices and output before (ex ante consequences) and after (ex post consequences) entry (or, more generally, rivalous investment) occurs. Part II examines the welfare properties of these three alternative rules.

Part III extends the basic model, which assumes that goods and services are supplied on a continuing basis, to cover equipment that undergoes significant design changes between successive production runs ("generational equipment"). A third case, which should be distinguished from both of these entry variants, is predatory pricing. among established firms. This case is treated in Part IV.

Part $\mathrm{V}$ applies the analysis to recent antitrust cases, and Part VI expressly sets out the proposed rules of law. The article concludes with a brief examination of the relation between predatory pricing rules and notions of industrial fairness.

\section{Predatory Pricing, Efficiency, and Strategic Modeling}

\section{A. The Issues}

The existence of predatory pricing has long been regarded with skepticism by many economists and some lawyers. Without objective standards defining predatory pricing, allegations of predatory pricing are easy to level but difficult to evaluate. Further, pricing "below cost" (variously defined) has been difficult to show empirically. ${ }^{7}$ Perhaps most persuasively, predatory pricing is held to be "irrational" since economic analysis suggests that it is always cheaper for a firm to acquire rather than to undersell a competitor. ${ }^{8}$

These arguments, however, are unpersuasive. As Professor Posner observes, the irrationality position "is convincing only if mergers are

6. Strategic behavior, in the context of predatory pricing, involves not merely prepositioning, which is standard to entry barrier analysis, but also contingent responses to entry. Both need to be examined in an integrated way.

7. See Areeda \& Turner, supra note 3, at 699 \& n.7; Koller, The Myth of Predatory Pricing: An Empirical Study, ANTITRust L. \& Econ. Rev., Summer 1971, at 105.

8. The standard reference on the purported irrationality of predatory pricing is McGee, Predatory Price Cutting: The Standard Oil (N.J.) Case, 2 J.L. \& EcoN. 137 (1958). For a commentary, see Yamey, Predatory Price Cutting: Notes and Comments, I5 J.L. \& EcoN. 129 (1972). 
assumed to be legal, and . . the illegality of mergers to create a monopoly has been clear for a long time now." If predatory pricing, though also unlawful, is more difficult to detect than merger, "predation may in fact be a cheaper mode of monopolization than acquisition." 10 Predatory pricing may also be used to influence the terms under which an acquisition is made ${ }^{11}$ and may be directed less at destroying extant rivals than at discouraging prospective rivals. ${ }^{12}$ The latter point is especially significant. The simple net benefit calculus upon which the irrationality argument rests can easily be upset if aggressive responses to entry in one market can have entry-deterring effects in other markets. If by responding aggressively to a current threat of entry a dominant firm can give a "signal" that it intends to react vigorously to entry in later time periods or different geographical regions, discounted future gains may more than offset sacrifices of current profit. Signaling, whether intertemporal or interspatial, is plainly strategic behavior. Areeda and Turner nevertheless model the predatory pricing issue mainly in static terms. ${ }^{13}$

\section{B. The Efficiency Criterion}

Lest the antitrust laws be invoked as a means to discourage legitimate rivalry, often as a shelter against inefficiency, workable criteria are sorely needed for distinguishing between meritorious and defective predatory pricing claims. Areeda and Turner reject "such empty formulae as 'below cost' pricing, ruinous competition, or predatory intent," and instead "attempt to formulate meaningful and workable tests for distinguishing between predatory and competitive pricing by examining the relation between a firm's costs and its prices." 14 Posner likewise eschews reliance on intent in evaluating claims of predatory behavior; he argues that intent is an unreliable indicator of market behavior. ${ }^{15}$ Without considerable confidence that a manifestly anti-

9. R. Posner, supra note 3 , at 185 .

10. Id. Cooper makes a similar argument. Cooper, supra note 3 , at 436 n.228.

11. Yamey, supra note 8 , at $130-31$.

12. R. POSNER, supra note 3 , at 185-86; Note, Telex v. IBM: Monopoly Pricing under Section 2 of the Sherman Act, 84 YALE L.J. 558, 564 n.27 (1975).

13. Occasional quasi-dynamic elements do appear, as in their treatment of promotional pricing. Areeda \& Turner, supra note 3 , at $713-15$. But the central argument and the main rules are developed in a static framework.

14. Arceda \& Turner, supra note 3, at 699-700. Areeda and Turner also "suggest that extreme care be taken in formulating [predatory pricing] rules, lest the threat of litigation, particularly by private parties, materially deter legitimate, competitive pricing." Id. at 699 .

15. R. Posier, supra note 3 , at 189-90:

A firm with executives sensitized to antitrust problems will not leave any documentary trail of improper intent; one whose executives lack this sensitivity will often 
competitive marketing plan is disclosed by the documents, and that the evidence is not just sales executive puffery, an enforcement effort based on intent is apt to be unrewarding.10

Both Areeda-Turner and Posner repeatedly assert that the "predatory impact" of a price reduction by a dominant firm must be judged by whether such a reduction will exclude an equally efficient rival. They presume that competition is running a beneficial course if the price cut excludes only firms that are less efficient than the dominant firm. To be sure, the demise of any firm has painful consequences for

create rich evidence of such intent simply by the clumsy choice of words to describe innocent behavior. Especially misleading here is the inveterate tendency of sales executives to brag to their superiors about their competitive prowess, often using metaphors of coercion that are compelling evidence of predatory intent to the naive. Any doctrine that relies upon proof of intent is going to be applied erratically at best.

16. Professor Scherer, in responding to Areeda and Turner, argues that cost-based approaches are simplistic and that a comprehensive appraisal of a complex set of economic facts together with an inquiry into the monopolist's intent is needed to reach a correct predatory pricing verdict. Scherer, Predatory Pricing and the Sherman Act: $A$ Comment, 89 Harv. L. Rev. 869, 890 (1976). Depending on the particulars, Scherer's "comprehensive reappraisal shows that long term economic welfare is maximized in some cases when the monopolist's price excecds its marginal cost and in other cases when marginal cost is undercut." Id, The particulars involve a determination of

the relative cost positions of the monopolist and fringe firms, the scale of entry required to secure minimum costs, whether fringe firms are driven out entirely or merely suppressed, whether the monopolist expands its output to replace the output of excluded rivals or restricts supply again when the rivals withdraw, and whether any long-run compensatory expansion by the monopolist entails investment in scale economy-embodying new plant.

Id. (footnote omitted). Scherer concludes that "I do not know how these variables can be assessed properly without a thorough examination of the factual circumstances accompanying the monopolist's alleged predatory behavior, how the monopolist's officials perceived the probable effects of its behavior (i.e., intent), and the structural consequences actually flowing from the behavior." Id.

Although $I$ also urge that greater knowledge of the circumstances is needed than uniform application of a cost-based standard admits, I am persuaded by Areeda and Turner's rebuttal that Scherer's approach relies on "long-run possibilities [that] are intrinsically speculative and indeterminate." Areeda \& Turner, Scherer on Predatory Pricing: A Reply, 89 HARv. L. REv. 891, 897 (1976) (footnote omitted). Scherer evidently would supplant antitrust enforcement with a price commission. Findings of illegality would turn on a study of full fact situations, including an examination of whether entrants are efficient or not. Where they are, the dominant firm would be constrained to charge a higher price than where they are not.

The exercise is troublesome on several accounts. Whether a price cut is predatory turns on whether or not entrants are efficient. (And if they are not, it is an easy step to extend the argument to consider the possibility that, given a "fair chance," they will be.) How the dominant firm is to be so apprised is not disclosed. Secondly, whether or not a price cut is predatory turns on whether it is subsequently reversed. But this involves monitoring for an indeterminate period. Among other things, it would be necessary to investigate whether a price is reversed or has been adjusted to meet new circumstances (for example, higher input costs or EPA restrictions). Dominant firm industries are easily converted to quasi-regulation in the process. But surely the record on price regulation counsels caultion. Rather than slip inadvertently into a regulatory posture-which, experience discloses, is typically hostile toward competition-antitrust is better advised to seek simple rules enforceable in court. 
the affected employees and investors. Seen in a broader context, however, the elimination of inefficiency is a leading benefit of competition. It is crucial to make the distinction between protecting competitors and protecting competition. Sentiment is a cruel hoax if it leads to protecting competitors, since the consumer is invariably the loser when such rules are introduced. An appreciation for the long-run efficiency benefits of competition is essential if the uncertainty that surrounds the law on predatory pricing is to be removed and useful rules are to be developed.17

Predatory pricing should thus be evaluated in efficiency terms. But whereas Areeda-Turner and Posner invoke static economic analysis to argue that marginal cost pricing promotes efficiency, this article formulates the problem in a more general way that makes express allowance for strategic considerations. The basic static economic proposition to which Areeda-Turner and Posner appeal is that, second best ${ }^{18}$ and strategic considerations aside, allocative efficiency is promoted by setting price equal to marginal cost. The underlying argument is that net social benefits are maximized when marginal social benefits (as reflected by price) are set equal to marginal social costs. AreedaTurner invoke both this condition and the less efficient rival criterion in arguing for a short-run marginal cost pricing test. ${ }^{19}$

There are technical problems with the less efficient rival claim and substantive problems with the allocative efficiency aspect of this twopart argument. The problem with the first part is that marginal costs are sometimes a poor indicator of total, and hence unit, costs. ${ }^{20}$ The

17. These uncertainties can be a major concern. "[U]ncertainties surrounding the process and criteria of judicial evaluation may deter much competitive activity that even courts would have found desirable." Cooper, supra note 3 , at 435.

18. Second best refers to the proposition that partial equilibrium analysis (which focuses on local conditions-e.g., a particular industry, rather than the whole economy) may be an unreliable indicator of overall welfare effects if sectors other than those being expressly investigated experience distortions. Though occasionally important, second best arguments are rarely operational and are commonly set aside. They are ignored in the remainder of this article.

19. They argue that "[i]f a monopolist produces at a point where price equals marginal cost, only less efficient firms will suffer larger losses per unit of output," and that if a firm is forced to charge a price greater than marginal cost, "[o]utput that could be produced at a lower cost than its value to consumers would be eliminated." Areeda \& Turner, supra note 3 , at 711 .

20. The types of problems that can arise here have been examined by Rosalind Seneca in the context of competition between alternative transportation modes. As she observes and demonstrates, "[a]llocating traffic to the mode with the lowest long-run [or short-run] marginal cost will not necessarily minimize the total cost of providing the service." Seneca, Inherent Advantage, Costs, and Resource Allocation in the Transportation Industry, 63 Am. Econ. Rev. 945, 946 (1973) (emphasis in original). To be sure, these problems may occur infrequently. Nevertheless, the contention that marginal cost prices accurately reflect relative efficiency. is in trouble from the outset. 
second part of the argument raises a more serious problem. Their allocative efficiency claims do not distinguish between marginal cost pricing of a continuing kind and temporary cutting of prices to marginal cost levels for strategic purposes. Marginal cost pricing on a continuing basis has the optimality properties to which Areeda and Turner refer. Moreover, temporary price cuts to marginal cost levels may be warranted by business exigencies other than strategic responses to entry. As Professor Cooper remarks, "[a]ny sale that returns a margin above the added cost of making that sale is unimpeachably sound business practice if it is the best available opportunity." ${ }^{21}$ Both of these practices, however, must be distinguished from the temporary cutting of prices to marginal cost levels for the strategic purpose of deterring entry. Although Areeda and Turner recognize that price reductions by the dominant firm may be rescinded when the entry threat vanishes, and express a clear preference for continuous marginal cost pricing, the only difference in the social benefits that they impute to permanent and temporary reductions is one of duration. ${ }^{22}$

An example may help to illustrate the problematic nature of the optimality properties associated with marginal cost pricing of an occasional, strategic kind. Consider a regulated public utility for which the regulatory authority, at periodic intervals, examines price-to-cost relations for the utility to ascertain whether the monopoly franchise should be renewed. Suppose that marginal cost pricing is favorably regarded by the authority and that the utility, recognizing this, adopts marginal cost pricing prior to each franchise review, but reverts to monopoly pricing as soon as the renewal is issued. How should these temporary price cuts be interpreted? The immediate benefit of such temporary price cuts will likely be negligible. Moreover, whatever the immediate benefits, long-run resource misallocations arguably result when the utility reverts to monopolistic pricing following each franchise renewal.

The insignificance of the immediate efficiency gains can be demonstrated by considering three cases: (1) the product or service is nonstorable and consumers recognize that the price cut is merely temporary; (2) the product is storable but the monopolist is unable to satisfy the demand for the product caused by the influx of orders from consumers attempting to increase their inventories; and (3) consumers mistakenly believe that the price cut will be permanent and adapt their investments accordingly.

21. Cooper, supra note 3 , at 437 .

22. Areeda \& Turner, supra note 3, at 706-11. 
There is little incentive to alter consumption practices under case (1) because consumers correctly perceive the temporary nature of the price cut and are unable to accumulate inventories. Here a temporary price cut mainly causes a transfer of income from the monopolist to consumers. Allocative efficiency is little affected.

Under case (2) consumers have an incentive to build up inventories in response to temporary price cuts. But the monopolist can satisfy these demands only if it has considerable excess capacity. Lacking excess capacity, a temporary low price can be sustained only by resorting to nonprice rationing-and hence inventory accumulation demands will go unfulfilled and the allocative effects will again be negligible.

The worst case is (3). If the price cut is thought to be permanent, when in fact it is temporary, consumers will be misled if they significantly alter their consumption practices. Negative net benefits can easily result if consumers incur significant fixed costs in adapting to what were thought to be permanent, but turn out to be temporary, changes in relative prices. Whatever the immediate responses to the price cut, in this example it is obvious that the price cut is merely a strategem. The regulatory authority is extremely myopic if it renews the monopoly franchise because prices are equal to marginal costs at the review interval, especially since more permanent price reductions could have been made a condition for franchise renewal.

To be sure, most of the dominant firms that are of concern here are not regulated industries. ${ }^{23}$ But the example is instructive nonetheless. The argument that temporary price cuts, whatever their motivation, yield negligible social benefits applies to regulated and unregulated firms alike. Areeda and Turner's appeal to social optimality as support for temporary marginal cost pricing is thus suspect. Furthermore, putting aside the differences between regulation and antitrust, there is a striking strategic similarity: the temporary price cut is designed in both instances to maintain a monopoly. ${ }^{24}$

Faced with strategic behavior of this kind, the basic question is

23. Charges of sales below cost do, however, arise between unregulated and regulated firms in the communications industry. The famous Telpak case was of this kind. American Tel. \& Tel. Co. (Telpak), 37 F.C.C. 1111 (1964); 38 F.C.C. 370 (1964). See also Note, Competition in the Telephone Industry: Beyond Telerent, 86 YALE L.J. 538 (1977) (examining Bell System's potential for subsidization of competitive services with monopoly revenues).

24. The example, however, breaks down thereafter. Thus the regulatory agency in the example is empowered to reassign the franchise itself, while a new entrant into an unregulated industry is not awarded a market share but makes inroads by actively contesting for sales. Furthermore, regulatory agencies are frequently able to reach and monitor price agreements on a continuing basis, while antitrust relies on the competitive process to perform this policing function. 
whether antitrust should tolerate or acquiesce in responsive pricing by dominant firms confronted by the prospect or fact of new entry, subject only to the condition that prices exceed marginal cost. I am inclined to regard price and output responses of a contingent kindnow it's there, now it isn't, depending on whether an entrant has appeared or vanished-as inherently suspect. At the very least, it would seem judicious to examine the properties of alternative predatory pricing rules before concluding that the allocative efficiency properties of marginal cost pricing on a contingent basis are beneficial.

\section{Strategic Behavior}

The analysis will be limited to firms that have a clear incentive to behave in a strategic way toward existing and potential rivals. Firms in competitively organized industries are exempted because the incentives are lacking. There is no purpose in sacrificing current profits unless offsetting gains in other geographical markets or in later periods are likely, and firms in competitive industries cannot reap these gains. ${ }^{25}$ Only in dominant firm and collusive oligopoly industries do firms have a clear incentive to exclude or eliminate rivals. Although behavior akin to predatory pricing can appear in loose oligopolies or even in competitively organized industries, such behavior is caused by breakdowns in pricing discipline or by personal animus and must be distinguished from the strategic efforts to acquire long-term market power that characterize predatory behavior by dominant firms and collusive oligopolies.

The analysis will be principally concerned with the response of dominant firms and collusive oligopolies to new entry. ${ }^{20} \mathrm{~A}$ dominantfirm industry can be defined as one in which the largest firm has a market share of at least sixty percent and entry into the market is not easy. ${ }^{27}$ Although only a few industries satisfy this definition for a na-

25. Areeda and Turner expressly recognize this and accordingly rely on the monopoly model to characterize demand and cost conditions. See Areeda \& Turner, supra note 3, at 698-99. Areeda and Turner make frequent references to "the monopolist" on the one hand and "new entrants and small firms" on the other.

26. Although the model applies to dominant firms and collusive oligopolists alike, for convenience dominant firm terminology is used throughout the article. The particular entry barrier model employed is a variant of the entry barrier analysis of Joe Bain and Franco Modigliani. See J. Bars, Barriers to New Competitron (1956); Modigliani, New Developments on the Oligopoly Front, $66 \mathrm{~J}$. Polirical Econ. 215 (1958). I am concerned with new investment, whether it is made by new entrants or fringe firms, rather than de novo entry per se. Again, however, it will be convenient to refer to new investment in new entry terms.

27. See O. Williamson, Markets and Hierarchies: ANalysis and ANTitrust Implicarions 208-33 (1975). Although the 60\% figure is not etched in stone, in defining dominant 
tional market, ${ }^{28}$ many more industries satisfy the conditions in geographic markets. In collusive oligopolies, firms are able to maintain an effective concurrence of market action. This is not, however, nearly so widespread a condition as is sometimes alleged, ${ }^{29}$ but occurs mainly in mature, highly concentrated industries producing homogeneous products under uniform cost conditions and having significant barriers to entry. ${ }^{30}$ Again, a consideration of geographic markets increases the number of markets that qualify as collusive oligopolies.

Since the welfare attributes of marginal cost pricing rules cannot be established abstractly, evaluation requires well-specified, operational, alternative rules. Three propositions guide this evaluation. First, postentry welfare differences aside, rules that invite greater pre-entry output restriction and higher-cost supply are plainly less favored. Second, for any given level of post-entry supply, social gains are realized whenever product is supplied at lower cost. Additionally, though less important and more difficult to characterize with the welfare economics apparatus used here, rules that require prospective entrants to have greater knowledge or to bear greater uncertainty are disfavored, ceteris paribus.

These propositions contemplate two kinds of strategic behavior. Temporary price cutting to marginal cost levels is transparently a strategem calculated to discourage current and future entry. This involves reactive (post-entry) behavior. But strategic considerations arise at the pre-entry stage as well. Each predatory pricing rule gives rise to pre-entry price, output, and investment adjustments on the part of dominant firms whose markets are subject to encroachment. To neglect the incentives of rules whereby dominant firms make pre-entry adaptive responses of a strategic kind necessarily misses an important part of the problem. ${ }^{31}$ Prior treatments are incomplete in that preentry effects are ignored, significant alternatives to marginal cost pricing rules are bypassed, and welfare effects are dealt with in a limited and overly sanguine fashion.

firms it must be recognized that disciplining rivals is costly. Only firms with a strong interest in the future configuration of an industry will be prepared to act unilaterally to influence such conditions.

28. See W. Shepherd, Market Power and Economic Welfare 151-53 (1970).

29. As the postwar Japanese and German experiences suggest, oligopolies behave rather differently from both the prewar holding companies (Zaibatsus) in Japan and the government-sanctioned cartel operations in Germany. J. Montias, The Structure of Economic SYSTEMS $187-90$ (1976).

30. O. WILLIAMSON, supra note 27, at 234-47.

31. I decided to formulate the problem in this way after reading a prepublication draft of A. Michael Spence's interesting paper, Entry, Capacity, Investment and Oligopolistic Pricing, 8 BELL J. ECON. 534 (1977), in which he investigates the use of capital investments as a barrier to entry. 


\section{Modeling Assumptions}

Dominant firms are assumed to be influenced by predatory pricing rules in the following way: ${ }^{32}$ whatever rule is in effect, dominant firms will invest in plant and equipment in an amount and kind such that the profits of any entrant, were one to appear, would be reduced to zero if the dominant firm responded to entry in the most aggressive manner allowed by the prevailing rule. ${ }^{33}$ An aggressive (as opposed to a conciliatory) response involves producing the maximum output consistent with the prevailing rule. Given that investment is determined with this strategic objective in mind, the dominant firm behaves in all pre-entry periods by maximizing short-run profits. Pre-entry investment and post-entry pricing behavior are thus both conditional on the specification of the predatory behavior rule.

The strategic model assumes that potential entrants are aware of and understand the economic consequences of entry responses by dominant firms under whatever rule is in effect. As in most entry models, potential entrants are assumed to assess their entry opportunities with respect to a residual demand curve, which shows how much market demand remains to be satisfied at every price given the dominant firm's contingent response to entry. ${ }^{34}$ The location of the

32. Alternative behavioral assumptions that involve no strategic prepositioning (myopic profit maximization) and sophisticated prepositioning of a probabilistic kind are examined at pp. 302-04 infra, and footnote 33 infra. As indicated there, few dominant firms are ignorant of the strategic relation they bear to the industry of which they are a part, which casts doubt on the assumption of myopia. Expected profit maximization in which probabilities are taken into account is more plausible. The model in the text easily generalizes to deal with this condition. The same qualitative arguments apply.

33. The analysis assumes that whenever a predatory behavior rule is specified the dominant firm will "locate" so that it can act within the law and still render entry unattractive.

The dominant firm faces the strategic problem of maximizing expected profits, recognizing that for each predatory pricing rule there is no unique price at or above which entry will surely occur and below which entry will never occur. Rather, the probability of entry varies directly with the price established by the dominant firm. Kamien \& Schwartz, Limit Pricing and Uncerlain Entry, 39 Econometrica 441 (1971); Williamson, Selling Expense as a Barrier to Entry, 77 Q.J. EcoN. 112 (1963). The analysis, however, is not greatly changed on this account. All that need be done is to recognize that a family of residual demand curves will be associated with each predatory pricing rule and a probability of entry attached to each. The dominant firm will then proceed to maximize expected profits by reference to these probabilistic demand curves. The same qualitative results characterizing rule differences, see pp. 295-304 infra, can be expected.

34. George Stigler, among others, has expressed serious reservations about limit pricing entry barrier analysis. As he puts it, the "ability of the oligopolist to agree upon and police the limit price is apparently independent of the sizes and numbers of oligopolists," whereupon the difficult issues of oligopoly theory are assumed away. G. STIGLER, THE ORGANizATION OF INDUSTRY 21 (1968). But the analysis presented in this article is expressly restricted to dominant firms and collusive oligopolists, as defined above. Oligopolistic industries not satisfying the delimiting conditions given in text are arguably unable to 
dominant firm's response curve depends on the dominant firm's preentry investment, and its shape depends on the prevailing predatory pricing rule. ${ }^{35}$

It will facilitate the analysis to make simplifying assumptions of three kinds. First, it will be assumed that, whatever rule is in effect, the dominant firm always chooses a plant design consistent with operating on the long-run average cost curve to which it has access. This assures that the plant design chosen satisfies rudimentary efficiency tests. Second, it is assumed that entrants have access to the same long-run cost curves as established firms. ${ }^{36}$ Third, it is assumed that the long-run average cost curve falls in steps rather than continuously. As will be shown in section B of Part II, relaxing these assumptions mainly buttresses the argument. ${ }^{37}$

\section{E. Alternative Rules}

Three rules for restraining dominant firms in the post-entry period will be investigated. The first rule is designated $Q \leq \boldsymbol{Q}$, where $\boldsymbol{Q}$ is the

engage in collective prepositioning and mutual policing as assumed in a strategic reaction curve model.

If dominant firms and collusive oligopolies are the relevant subset, then the basic issue is whether predatory pricing rules are appropriately described in terms of strategic response functions. If so, residual demand curves for potential entrants may be obtained in the manner described below. Academic diferences about entry models and their limited applicability to certain types of oligopoly thus miss the point. What matters is whether the strategic considerations are critical and, if they are, if they are adequately reflected in the modeling apparatus employed.

35. For the purposes of this article, I will assume that the shape of the dominant firm's response curve is fully determined by the prevailing predatory pricing rule. Thus, if a marginal cost pricing rule were adopted, the response curve would be the dominant firm's marginal cost curve. Actually, legal rules place an outer bound on admissible responses rather than uniquely determine them. The qualitative results obtained below stand up provided that Iegal rules have the general effects attributed to them.

36. This ignores a strategic asymmetry between established firms and potential entrants. However qualified the latter may be, they have not made the investment in fixed plant and operating infrastructure that established firms have. Accordingly, new entrants have to persuade investors to make funds available while established firms are not required to make similar appeals. Threats by established firms to contest entry vigorously can thus affect the terms on which capital becomes available to the potential entrant, while the potential entrant is not able to impose similar costs on the established firm.

Once entry has occurred, entrant and established firm are more on a parity in this respect-unless entry has occurred in a tentative way $(e . g$., the entrant has leased general purpose equipment rather than bought special purpose equipment). The incentives for the dominant firm to engage in short-run predatory behavior are especially strong where entry is plainly tentative.

37. I also assume that effective entry can rarely be assured by resorting to long-term contracting. The dominant firm can be expected to contest pre-entry sales just as it contests post-entry sales. Also, prospective customers would be reluctant to jeopardize a known source of supply before the entrant has irreversibly committed himself by incurring fixed costs. Finally, long-term contracts are both costly and hazardous. See O. Williasison, supra note 27 , at pp. 82-105. 
dominant firm's pre-entry level of output and $Q$ is the post-entry level of output. This rule, called the "output restriction rule," stipulates that in the period after entry occurs the dominant firm cannot increase output above the pre-entry level. It is essential to specify the time period over which the output restriction rule holds. Unless predatory responses to new entry quickly threaten the viability of the new entrant, such responses are unlikely to be effective. As discussed below, the cost disadvantages of new entrants decrease as they accumulate experience and demonstrate their viability. Ordinarily an initial restraint period of twelve to eighteen months is sufficient to allow the entrant to realize cost economies and establish a market identity.$^{38}$ A shorter period would permit the dominant firm to hold excess capacity as a strategic reserve to be unleashed at the end of the grace period, and a longer period rould pose severe administrative problems and weaken the incentives of new entrants quickly to achieve cost parity with the dominant firm.

The second rule, designated $\mathrm{P} \supseteq S R M C$ (where $\mathrm{P}$ is price and $S R M C$ is short-run marginal cost), permits the dominant firm to increase output in the post-entry period subject to the condition that price not fall below short-run marginal cost. This is called the "marginal cost rule." The third rule, designated $\mathrm{P} \supseteq S R A C$ (where $S R A C$ is short-run average cost), permits output expansion if the resulting price exceeds short-run average cost. This is called the "average cost rule." 39

Consider first the price and output of a monopolist not threatened by entry. These are shown in Figure 1 as $\mathrm{P}^{*}$ and $\mathrm{Q}^{*}$, respectively, and represent the short-term profit-maximizing position. This is the price and output at which marginal revenue (denoted $M R$ in the figure) is just offset by, and is thus equal to, the marginal cost of the last unit sold. Consider now how price and output are affected if dominant firms are concerned with entry and a predatory pricing rule is in effect. The three alternative rules and their effect on entry will be considered in turn.

38. Moreover, the recent entrant is not defenseless but enjoys the protection of the law, albeit in the capacity of an "established" firm, once the initial period has expired. The rules appropriate for evaluating predatory pricing among established firms are set out at pp. 336-37 infra.

39. These rules are not exhaustive. The most conspicuous omission is the proposal that dominant firms faced with new entry must maintain price until the entrant has had an opportunity to become established. Such a rule requires dominant firms to hold up a "price umbrella," which implies an output reduction by dominant firms and is an invitation for inefficient firms to enter. The inferior welfare properties of a rule having these implications are, I believe, obvious. See p. 328 \& note 109 infra. 




\section{The Output Restriction Rule, $Q \leq Q$}

The basic rule allows the dominant firm to operate at $Q=Q$, but the rule must be qualified by a requirement that the resulting price exceed average variable costs when output is held unchanged. ${ }^{40}$ This qualification will normally be satisfied. ${ }^{41}$

\section{a. $Q=Q$}

The behavioral assumption on which most entry barrier analysis is based is that "potential entrants behave as though they expected exist-

40. The operational import of this qualification is slight, however. It mainly allows for remote contingencies and tidies up the model.

41. Indeed, earlier entry barrier models have ignored altogether the remote possibility that the post-entry price would fail to cover the dominant firm's average total cost. Inasmuch as $A T C>A V^{\prime} C$ when the dominant firm is operating at $Q_{0}$, see Figure 1 and note 122 infra, the $A V C$ constraint is even less likely to be violated if the dominant firm holds its output unchanged. 
ing firms to adopt the policy most unfavorable to them, namely, the policy of maintaining output while reducing the price (or accepting reductions) to the extent required to enforce such an output policy." 42 The basic model is shown in Figure 1. The curve $D$ is the industry demand curve and $L R A C$ is the long-run average cost curve accessible to existing firms and potential entrants. ${ }^{43}$ The curve $D^{\prime}$ is the residual demand curve, which shows the amount of demand remaining when the dominant firm holds its output unchanged. Taking $Q_{0}$ as the dominant firm's pre-entry output, so that the firm may not supply more than $Q_{0}$ in the immediate post-entry period (twelve to eighteen months), residual demand is that part of the demand curve to the right of $Q_{0}$. The curve labeled $D^{\prime}$ represents the horizontal displacement of this residual demand curve to the origin.

Given that the dominant firm chooses investment such that the prospective entrant can at best earn zero profits on the residual demand curve, the dominant firm's object is to select $Q_{0}$ such that $D^{\prime}$ is just tangent to (never exceeds in value) the long-run average cost curve. This tangency occurs at the point denoted by $T$ in the figure. Were the dominant firm to supply less than $Q_{0}$ in the pre-entry period, $D^{\prime}$ would be shifted to the right and the new entrant could earn positive profits under the output restriction rule. If, however, the monopolist charges the price $P_{0}$ and produces $Q_{0}$, the best that a potential entrant could hope for under the output restriction rule is to break even by constructing a plant and producing an output of size $Q_{\mathrm{r}}$. Any entering firm that produces an output larger or smaller than $Q_{\mathrm{T}}$ will not be able to cover its costs, since the residual demand curve lies below the LRAC curve at all other points.

The dominant firm's pre-entry output and price $\left(Q_{0}\right.$ and $P_{0}$, respectively) differ from the unconstrained profit-maximizing position ( $Q^{*}$, $\mathrm{P}^{*}$ ) due to the threat of entry. But for the threat of entry, the monopolist would set marginal revenue ( $M R$ in the diagram) equal to marginal cost ${ }^{44}$ by producing an amount $Q^{*}$, which is less than $Q_{0}$. The price at which the quantity $Q^{*}$ clears the market exceeds the market-clearing price for the quantity $Q_{0}$, so that $P^{*}>P_{0}$.

Even though potential competition serves to restrict the monopolist's profit margins, pre-entry operation at the limit price $\left(\mathrm{P}_{0}, \mathrm{Q}_{0}\right)$ nevertheless yields supracompetitive profits. Only if the monopolist were

42. Modigliani, supra note 26 , at 217.

43. If potential entrants have to incur set-up costs, allowance must be made to recover these during the anticipated production interval.

44. Note that short-run and long-run marginal costs are equal when plant size is adjusted optimally to produce the amount $Q^{*}$. 
to expand pre-entry output to the level $Q_{c}$, where price is equal to long-run average cost, ${ }^{45}$ would his economic profits vanish. Although output at the level $Q_{\mathrm{C}}$ is socially preferred to output at $Q_{0}$, the former is unattainable short of regulation-which, by assumption, is disallowed. ${ }^{4 \mathrm{~B}}$

If entry occurs and additional supplies of amount $Q_{\mathrm{T}}$ are brought onto the market, the resulting market price $\left(\mathrm{P}_{\mathrm{T}}\right)$ still exceeds the monopolist's costs of production (at $Q_{0}$ ). Thus, although the new entrant just breaks even at the point $\left(\mathrm{P}_{\mathrm{T}}, \mathrm{Q}_{\mathrm{T}}\right)$, the dominant firm continues to realize positive, albeit reduced, post-entry profits. Differential profits between large and small firms in concentrated industries are thus a predictable consequence of the entry barriers model. ${ }^{47}$

\section{b. $Q<Q$}

In the unlikely event that the new entrant brings onto the market a quantity of output so large that, if the dominant firm holds its output unchanged, price is driven below the dominant firm's average variable costs, the dominant firm (and entrant, if the entrant is selling below its average variable costs) should be required to reduce output until a $\mathrm{P} \supseteq A V C$ result is realized. ${ }^{48}$ Absent this stipulation, dominant firms that held output unchanged irrespective of entry might occasionally drive prices below remunerative levels in the immediate post-entry period. The $\mathrm{P} \supseteq A V C$ requirement forestalls this possibility.

\section{The Short-Run Marginal Cost Rule, $\mathrm{P} \supseteq S R M C$}

Suppose instead that the monopolist is permitted to expand output when confronted with entry, and that his only restriction is that price should not be reduced below short-run marginal cost. Assume, for purposes of evaluating this possibility, that in response to entry the monopolist chooses to expand output until price precisely equals

45. It is assumed that the demand curve intersects the long-run average cost curve in the region where $L R A C$ is flat. This seems reasonable for most industries in a large cconomy such as the United States.

46. Regulation is beset with numerous difficulties of its own. Where competition can be made to work reasonably well, it is usually to be preferred.

47. The evidence is consistent with this prediction. See Demsetz, Two Systems of Belief About Monopoly, in Industrial Concentration: The New Learning 164 (H. Goldschmidt, H. Mann \& J. Weston eds. 1974).

48. See, howerer, pp. $324-25$ for the qualifications that allow entrants to engage in promotional pricing of short duration for consumer nondurables. Although entrants might price below average variable costs temporarily under this exception, no massive market dislocations would be permitted. 
marginal cost. What are the entry and output implications of contingent output responses of this kind?

Figure 2 depicts the relationships with the marginal cost rule in effect. Since the monopolist is permitted under this rule to respond to new entry by expanding output, ${ }^{49}$ he can safely reduce pre-entry output below $Q_{0}$ without inducing entry. The optimum level of investment is again determined by the residual demand curve. But whereas previously the residual demand curve was given by $D-Q_{0}$, now it is given by $D-S R M C$, since the monopolist can expand output as long as price remains above short-run marginal cost. The optimal scale can be obtained graphically by considering the family of plant scales con-



49. Plainly the output unchanged rule is not the "most unfavorable" behavior that an entrant could impute to existing firms in the industry, see pp. 297-98 supra; output cxpansion as a reply to entry is more adverse. 
sistent with operating on the long-run average cost curve ${ }^{50}$ and finding the horizontal difference between the corresponding short-run marginal cost curve of each such plant and the demand curve, $D$. The plant scale for which there is a point of tangency between the residual demand curve, thus defined, and the long-run average cost curve $(L R A C)$ is then the optimal plant scale for the dominant firm. As shown in Figure 2, the plant scale with $S R M C$ curve yielding this tangency has minimum short-run average costs at output $Q_{\mathbf{x}}$.

Once a plant of this scale is put in place in the pre-entry period, the monopolist will choose the output that maximizes his profits. This entails equating industry marginal revenue with the short-run marginal costs corresponding to plant scale $\mathrm{Q}_{\mathrm{x}}$. The monopolist thus produces the amount $Q_{2}$ (which is less than $Q_{0}$ ) and charges the price $P_{2}$ (which exceeds $\mathrm{P}_{0}$ ). Were entry to occur, however, the monopolist would respond by operating where price equals marginal costs. This would involve a movement along his $S R M C$ curve until he reaches the output $Q_{0 .}{ }^{.1}$ The prospective entrant, in anticipation of this output response, will not enter unless price exceeds $\mathbf{P}_{2}{ }^{52}$ Thus a prospective entrant will enter only if the monopolist has chosen too small a plant, so that his short-run marginal costs exceed $P_{x}$ at output $Q_{0}$.

\section{The Short-Run Average Cost Rule, $\mathrm{P} \supseteq S R A C$}

A similar investigation can be made of the average cost rule. Inasmuch as the average cost curve is flatter than the marginal cost curve, the residual demand curve (given by the horizontal difference $D-$ $S R A C)^{53}$ is likewise flatter. It will be convenient to assume, however, that the tangency between the resulting residual demand curve and the long-run average cost curve remains at the point $T$, where the cost curve is kinked. The optimum plant scale is thus that plant scale for

50. For a discussion of long-run cost curves and their relationship to short-run cost curves, sce Viner, Cost Curves and Supply Curves, Zeitschrift für Nationalökonomie (1931), reprinted in Readings IN PrICE THeory (K. Boulding \& G. Stigler eds. 1952).

51. Market price is determined by aggregate supply. Given that the entrant supplies $Q_{T}$, the ruling market price will be $P_{T}$ if the dominant firm supplies $Q_{0}$. The dominant firm's short-run marginal cost of supplying $Q_{0}$ is $P_{T}$ by construction (otherwise the residual demand curve would be differently located).

52. The prospective entrant assumes that the dominant firm maximizes profits given its plant scale in the pre-entry period. Given this assumption, if the dominant firm's pre-entry price exceeds $P_{3}$, the dominant firm that responds along its short-run marginal cost curve will be unable to eliminate positive profits for an entrant that accurately perceives the industry opportunities.

53. The residual demand curve is here given by the difference $D-S R A C$ because at any price, $P$, the most that the dominant firm can supply without violating the averagecost rule is the quantity where $\mathrm{P}=S R A C$. Hence the entrant is assured that at any price the amount $D-S R A C$ will be the minimum demand left unfilled by the dominant firm. 
which the short-run average cost curve passes through the point $\left(P_{r}\right.$, $\left.\mathrm{Q}_{0}\right)$.

Optimum plant scale under the $S R A C$ rule is necessarily smaller than $\mathrm{Q}_{\mathrm{r}}{ }^{54}$ Accordingly, the output at which the dominant firm's short-run marginal cost is equal to industry marginal revenue will be less than $Q_{2}$. Pre-entry price will thus exceed $P_{2}$.

\section{F. Innocent Profit Maximization}

Thus far the analysis of the three predatory pricing rules has assumed that dominant firms position themselves so that they can exclude potential entrants without violating the predatory pricing rule. But what if dominant firms do not follow this strategy? Will a change in strategy call for a different predatory pricing rule? Suppose, arguendo, that the dominant firm is myopic and simply maximizes profit in every period without regard to strategic pre-entry positioning or postentry extinction of its rival. Is the output restriction rule apt to preclude simple nonstrategic responses of this kind? If so, should it be abandoned from the outset?

The answer is that nonstrategic or myopic responses by dominant firms will, under plausible assumptions about the behavior of entrants, normally lead to an output reduction (which is a conciliatory response) by dominant firms, in which case the output restraint will be satisfied. Thus, consider three scenarios. Although the dominant firm is assumed to maximize profits with respect to its residual demand curve under each scenario, the behavior imputed to entrants is assumed to vary.

In the first scenario, the new entrant is assumed to maintain output unchanged in the immediate post-entry period: it enters at $Q_{\mathrm{T}}$ and continues to supply $Q_{\mathbf{T}}$ during the post-entry interval. The residual demand curve of the dominant firm is thus the horizontal difference between the industry demand curve and $Q_{\mathrm{T}}$. The dominant firm that maximizes profits by setting marginal cost equal to the corresponding (residual) marginal revenue curve will, under this scenario, always reduce output below what it had supplied in the pre-entry period.

Suppose, alternatively, that the new entrant and dominant firm behave symmetrically in that each assumes that its rival will supply an amount of product in the next period identical to the amount that the rival supplied in the current period. The corresponding residual de-

54. This follows because the response curve of the dominant firm under the $S R A C$ rule is the curve $S R A C$, which is flatter than $S R M C$ and thus allows the dominant firm to respond to entry by bringing greater post-entry product onto the market than would be the case if an $S R M C$ rule were in effect, ceteris paribus. 
mand curve of each will then be given by the industry demand curve less the recent output of its rival. Firms behaving in this myopic fashion will converge to a solution that implies an output reduction for the dominant firm..$^{55}$ Again, the output restraint is redundant.

Suppose, thirdly, that the new entrant treats market price as a parameter and adjusts output so as to supply at every price the amount of product that equates price with short-run marginal cost. Suppose, further, that the dominant firm accurately perceives that the new entrant responds to price changes in this way. The residual demand curve to which the dominant firm now refers is the horizontal difference between the market demand curve and the marginal cost curve of the new entrant. The output supplied by the dominant firm after entry then becomes a function both of the entrant's marginal cost curve and its own marginal cost curve. The shapes of both marginal cost curves thus jointly determine whether the dominant firm will supply more or less product following entry. It is conceivable under these circumstances that a strategy of equating marginal cost to marginal revenue on the residual demand curve would lead to an output increase by the dominant firm. ${ }^{56}$ This is, however, merely a hypothetical possibility. Operationally it seems unlikely. Not only must the shortrun marginal cost curve of the entrant be of a special kind, but the immediate post-entry behavior imputed to the new entrant is myopic and implausible.

It is important to recognize that the current costs of new entrants normally exceed the costs that the entrant will incur in later periods, due to the benefits that accrue to experience. Inexperienced but otherwise qualified firms are often at a disadvantage to established firms in two respects: they do not have an experienced work force ${ }^{57}$ and they

55. This is the normal Cournot solution. See F. Scherer, Industrial Market Structure AND ECONOMIC PERFORMANCE 132 (1971).

56. The qualitative output response of the dominant firm in these circumstances is indeterminatc. It depends on the position and relative slopes of the dominant firm's and entrant's marginal cost curves and on the industry demand curve.

57. If workers appropriated all of the benefits of idiosyncratic training and experience, so that productivity differences between experienced and inexperienced work forces would be fully reflected by wage differentials, the labor force disadvantage of new entrants would vanish. Alternatively, if wages did not fully reflect the increased productivity of experienced workers, but the new entrant could raid the dominant firm and hire talent away easily, the work force disability would vanish. If, however, neither of these conditions were satisfied-which is to say that idiosyncratic advantages are incompletely appropriated by workers and wage premiums have to be offered to bring talent from the established firm to the new entrant-the new entrant would suffer a work force disadvantagc. As I have argued elsewhere, the incomplete appropriation and wage premium conditions are common. O. Williasison, supra note 27 , at $72-78,216-17$. The new entrant thus often suffers a temporary cost disadvantage until learning-by-doing brings the entrant's labor force to a level of experience and productivity comparable to the dominant firm's. 
may be perceived as high-risk ventures. ${ }^{58}$ Post-entry competition commonly serves to mitigate both of these conditions. Learning-by-doing economies accrue to the labor force and experience is often the least expensive method by which the entrant can convince investors that it possesses the requisite management talent and perseverance to compete effectively. Unless, therefore, a dominant firm can arrest and reverse an entry incursion quickly, the relative costs of continuing a predatory campaign shift to the dominant firm's disadvantage and the prospects of successful entry improve.

Given the advantages of perseverence, it seems unlikely that a new entrant would curb output in order to behave in the manner described by the third scenario. Rather, the new entrant will maintain or increase its supply in the immediate post-entry period, as assumed by the myopic dominant firm in the first two scenarios. The myopic dominant firm (seeking continuously to equate marginal revenue to marginal cost) thus arguably refers to a residual demand curve that calls for a post-entry output reduction. The output restriction rule is therefore redundant if nonstrategic profit maximization is practiced by the dominant firm. ${ }^{50}$

58. New entrants may be perceived as high-risk ventures because they are relatively risky according to an objective standard or because, though they possess the requisite management and other talents to compete effectively, it is very costly to disclose their competitiveness in a compelling way to potential investors. Id. at 110-13. An entrant can make a more compelling case for its competitiveness by presenting evidence of demonstrated ability to achieve cost control and a demonstrated commitment to persevere under difficult circumstances than it can using ex ante representations on these matters.

59. A variant of the innocent profit maximization argument is that dominant firms maximize profits at the point $\left(P^{*}, Q^{*}\right)$ in the pre-entry period heedless of the threat of entry and heedless of whatever predatory pricing rules are declared. Accordingly, preentry price and output are identical for all of the predatory pricing rules. To the extent that setting price equal to marginal cost in the post-entry period maximizes welfare, the $P \geq M C$ rule is arguably superior and should be approved.

The argument is troublesome on several counts. For one thing, it assumes that dominant firms are massively unsophisticated. A more plausible proposition is that persistent dominance is a prima facie indicator that the dominant firm in question has keenly appreciated the strategic relation it bears to its industry. Dominant firms that price heedless of entry will rarely maintain their market positions.

It has been suggested that the Spence model demonstrates that setting marginal revenue equal to marginal cost in the pre-entry period and price equal to marginal cost in the post-entry period is the "rational" strategy and that this is exactly what the AreedaTurner rules permit. See Spence, supra note 31 . The correspondence exists, but the Spence model assumes that price will be set equal to marginal cost in the post-entry period rather than demonstrates that this is the unique profit-maximizing strategy.

One of the arguments that Spence invokes in support of the assumption that $\mathrm{P}=\mathrm{M} C$ post-entry is that the appearance of a new entrant causes the pre-entry condition of oligopolistic collusion to break down. Although loose oligopolies may well revert to marginal cost pricing when entry occurs, the Nash logic upon which Spence relies applies neither to dominant firms nor collusive oligopolies (of the special kind described in the 


\section{G. Differential Enforceability}

In choosing among predatory pricing rules, an important consideration is the relative difficulty of enforcing the rules. An output rule should be easier to enforce than a marginal cost rule. The ease with which theoretical cost functions can be used to secure analytical insights should not obscure the very real difficulties encountered in any attempt to make precise empirical studies of these functions. Standard accounting costs rarely bear a close relation to an economist's conception of cost, especially when marginal cost estimates are required.

Since estimates of short-run marginal cost involve an enormous amount of judgment, a marginal cost test would be a defendant's paradise. The time period across which costs are to be allocated is disputable, as is any decision about which costs to include. Allocations of overhead, especially in a multi-product enterprise, can be juggled, and inventories can be valued differently under different rules. Either a standard or an actual cost argument can be made, depending on which suits the litigant's purposes. The list goes on, as different cost variances can be treated differently, with each estimate supported by a plausible, though ad hoc, rationale. The upshot is that estimation of short-run marginal costs is a mare's nest. It is unrealistic to expect a judge or jury to sort out the various representations.

To be sure, establishing the admissible level of output $(Q)$ entails a demand forecast rather than simple reference to pre-entry period production. Except, however, for products where period-by-period demand is subject to severe stochastic disturbances, this should not pose a serious problem. The test is especially simple for products that are sold in many separate geographic markets. Since only one or a few of these submarkets are apt to occasion claims of predation, the test is whether output in the suspect markets has increased disproportionately. In other circumstances a simple trended average of recent sales will give an estimate accurate to within five percent of realized demands. A ten percent allowance over the trended projection will be adequate for

text). Restricting attention to these, a post-entry response function of the $\mathrm{P}=\boldsymbol{M C}$ kind can be asserted but it cannot be said to hold uniquely by reason of necessity or competitive self-interest.

Additionally, for the reasons set out above, see pp. 292-95 supra, temporary marginal cost pricing yields negligible immediate welfare benefits. If alternative rules of a nonprotectionist kind can be devised which less severely deter entry (in other geographic regions or in later periods) than does temporary marginal cost pricing, net negative welfare consequences may well be associated with reaction functions of the marginal cost kindeven if dominant firms have made no effort to position themselves strategically in the pre-entry period. 
most cases, ${ }^{60}$ and such an allowance will scarcely permit the dominant firm to effect a massive market dislocation of the kind a marginal cost rule would often permit. Business planning records and industry forecasts can be examined for corroboration of the trended estimates, and more sophisticated demand projection tools are available if needed. Thus the output rule, although not problem free, is eminently more enforceable than the marginal cost rule (or even the average variable cost surrogate) favored by Areeda and Turner. ${ }^{61}$

\section{Welfare Evaluation of Predatory Pricing Rules}

As is characteristic of most applied welfare economics studies, the analysis in this Part focuses entirely on a local condition-in this case,

60. Special circumstances can be imagined where appropriate demand adjustments would be difficult to make. For example, an oil embargo may give rise to a temporary spurt in natural gas sales. I am unaware of predatory pricing claims in such circumstances and have no reason to believe that such claims typically have arisen or will arise in circumstances involving an unusual demand shift.

61. The argument has been made that it is optimal to require the dominant firm to hold output unchanged in the event of entry. The question arises whether it is optimal to place the same restriction on the dominant firm's other activities, such as selling expense or research and development. The answer is no, though for somewhat different reasons.

The output restriction rule has the twofold purpose of giving new entrants a threshold opportunity to become established and of discouraging dominant firms from ominously holding excess capacity in reserve. Dominant firms may hold up the introduction of technological developments for strategic purposes, but the risks of holding completed developments off the market for very long are severe. Since trade secrets are fugitive and rivals are apt to market a similar product before the dominant firm, this contingency does not appear to be very serious. In any event, technological developments held in reserve would be difficult for courts to evaluate and control. Moreover, research and development spending in response to new entry will rarely pose an immediate threat to the viability of new rivals. Rather, research and derelopment responses should be interpreted mainly in the context of long-run rivalry, in which case it seems reasonable to exempt research and development and other long-run manifestations of rivalry from antitrust control over predatory behavior-subject only to the usual long-run cost recovery stipulation. (The usual controls on patent infringements, trade secret pirating, etc., would, however, continue.)

Selling expense, on the other hand, arguably does have short-run impact. Should it be regarded symmetrically with ontput, adding a constraint $S \leq S$ (where $S$ is selling expense and $S$ is the level of selling expense in the pre-entry period) to the $Q \leq Q$ rule? Although this proposal has superficial appeal, the purported symmetry between selling expense and output is mistaken, since selling expense is really an alternative to price reductions as a means of influencing post-entry sales. The dominant firm would be permitted to choose any combination of price and selling expense consistent with the condition that price exceeds short-run marginal costs when output remains in the $Q \leq Q$ range.

A possible exception might be warranted where selling expense is thought to have pernicious social effects. This is, however, more difficult to ascertain than is commonly believed. Indeed, such products will presumably be subject to special controls prior to any effort to enter, in which case additional entry restraints are not needed. Note, moreover, that selling expense is simply an unproductive way by which to discourage entry in most homogeneous product and/or producer good industries. Except for consumer good industries where products are heavily promoted to emphasize real or imagined differences, selling expense vanishes as a predatory technique. 


\section{Predatory Pricing}

on the industry in which a risk of predation is believed to exist. Second order interactions between this industry and other parts of the economy are ignored. The object of the inquiry is to ascertain differential welfare effects attributable to the three alternative predatory behavior rules set out in Part I. Social benefits will be taken to be the area under the demand curve between the origin and the quantity of goods that is sold. This area represents the gross gain that consumers receive from the product. Social costs will be interpreted in terms of opportunity costs: costs are defined as the value in their best alternative employments of the resources used to supply the product. It will simplify the analysis, and will have no effect whatsoever on the qualitative nature of the results, to assume that social costs are accurately reflected by the pecuniary costs incurred by the dominant firm and new entrants to the industry. ${ }^{62}$

\section{A. Application}

Two kinds of effects of predatory pricing rules must be examined. First, what is the effect of each rule on pre-entry welfare? This aspect of the problem has previously been neglected. Second, how do the rules affect post-entry supply? Although prior treatments have dealt with this second question, the issues have not been developed expressly in terms of the differential effects of proposed rules on the cost of post-entry supply.

\section{Pre-Entry Welfare}

The pre-entry welfare differences among rules can be examined in two parts: an output effect (will more or less output be supplied if a rule change is made?); and the cost of supply (do the average costs of supplying product differ under alternative rules?).

It will be convenient to use the output restriction rule as the standard by which to evaluate the welfare effects of adopting different rules. With the output restriction rule in effect, pre-entry supply will be $Q_{0}$ and the corresponding average costs will be $A C_{0}$. As discussed

62. No corrections (by reason of externalities, factor rents, or the like) to the cost curves shown in the preceding section are thus required for social cost accounting. To be sure, this is a simple: apparatus and a variety of refinements can be introduced. See Harberger, Three Basic Postulates for Applied Welfare Economics: An Interpretive Essay, $9 \mathrm{~J}$. ECON. Literature 785 (1971). It is noteworthy, however, that defects in the apparatus are more severe if measures of total welfare are attempted (e.g., should the product be supplied at all) rather than, as here, with an examination of the marginal welfare differences attributable to rule changes. Differential welfare effects are much less affected by measuring rod defects when the welfare measures of interest involve evaluating the incremental effects of rule changes on prices and quantities within a local region. 
earlier, ${ }^{63}$ permitting firms to respond to entry under the marginal cost rule induces the dominant firm to reduce pre-entry supply from $Q_{0}$ to $Q_{2}$, whereupon price increases from $P_{0}$ to $P_{2}$. But the costs of supply also change. Pre-entry product is supplied at an average cost of $A C_{2}$ under the marginal cost rule, and $A C_{2}$ exceeds $A C_{0}$.

The pre-entry welfare losses of shifting from the output restriction rule to the marginal cost rule are shown in Figure 3. The area $A_{1}$ is the loss resulting from output reduction; the area $A_{2}$ is the loss attributable to the higher average cost. Plainly, the output restriction rule is superior to the marginal cost rule in terms of pre-entry welfare.

The average cost rule can be evaluated in the same way. The rule causes further output reductions in the pre-entry period, and the average cost of supplying the reduced amount of product will exceed $A C_{0}$. The average cost of supplying product in the pre-entry period under the average cost rule may or may not exceed $A C_{2}$. If the average costs do not exceed $A C_{2},{ }^{64}$ the average cost rule may or may not be in-



63. See pp. 300-01 supra.

64. If the $S R A C$ curve for the small plant scale that obtains under the average cost rule is merely a horizontal displacement to the left of the $S R A C$ curve that obtains under 


\section{Predatory Pricing}

ferior to the marginal cost rule in pre-entry welfare loss respects. It is plainly inferior, however, to the output restriction rule.

\section{Post-Entry Welfare}

Recall that the product supplied by the dominant firm in the postentry period is $Q_{0}$ under each of the rules. Also recall that the entrant supplies $Q_{\mathrm{T}}$ in the post-entry period under each rule. Total post-entry product $\left(Q_{0}+Q_{T}\right)$ is thus identical under all rules. ${ }^{65}$ The welfare differences among the rules turn entirely, therefore, on cost differences.

Since the entrant's costs of supply are identical for all three rules (namely $A C_{\mathrm{T}}=\mathrm{P}_{\mathrm{T}}$ ), the cost differences among the rules depend entirely on the costs incurred by the dominant firm in supplying $Q_{0}$. The relevant cost relations are shown in Figure 4 . The average cost of supplying $Q_{0}$ under the output restriction rule is $A C_{0}$. When the marginal cost rule is in effect, average cost will be $A C_{0}{ }^{2}$, which exceeds $A C_{0}$ but is less than $\mathrm{P}_{\mathrm{T}^{*}}$. When the average cost rule is in effect, the

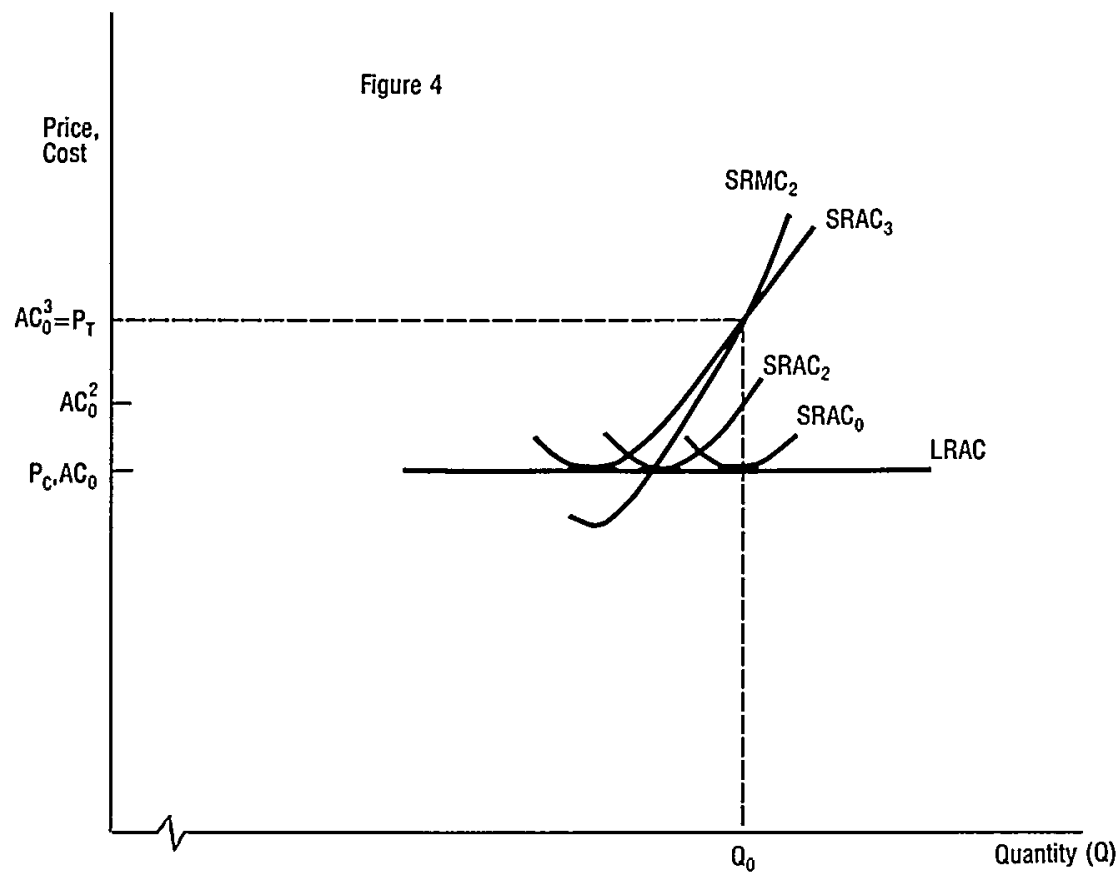

the marginal cost rule, average costs will be lower than under the marginal cost rule since marginal cost under the marginal cost rule will intersect marginal revenue at a value that is closer to the minimum point on the $S R A C$ curve.

65. It will be shown, see p. 315 infra, that this an artifact of the stepwise longrun average cost curve that has been constructed. 
average cost of supplying $\mathrm{Q}_{0}$ will be $A C_{0}{ }^{3}$, which is equal to $\mathrm{P}_{\mathrm{r}}{ }^{60}$ Since $A C_{0}<A C_{0}{ }^{2}<A C_{0}{ }^{3}$, there is a clear post-entry welfare ordering of rules, whereby the output restriction rule is superior to the marginal cost rule, which in turn is superior to the average cost rule. Moreover, a rank ordering of rules according to the average variable cost of supplying $Q_{0}$ in the post-entry period-which arguably is the better measure of social $\operatorname{cost}^{67}$-will normally yield an identical result.

\section{Conclusion}

The output restriction rule is thus superior to the alternative rules with respect to both pre-entry and post-entry welfare. The marginal cost rule is probably superior to the average cost rule in its effect on pre-entry welfare and is clearly superior in its effect on post-entry welfare. The partial equilibrium welfare analysis thus yields the following rank ordering of rules: the output restriction rule is best; the marginal cost rule is probably second; and the average cost rule is probably third.

\section{B. Extensions}

The partial equilibrium analysis in the preceding section has, necessarily, been based on numerous assumptions. Although all possible complications cannot be considered, this section will discuss three issues: the welfare implications of Areeda and Turner's average variable cost formulation of the marginal cost rule; the effects of information needs and uncertainty on the ordering of the rules; and the welfare effects of relaxing the three simplifying assumptions made in Part I.

\section{Average Variable Cost}

In view of the difficulties in measuring marginal cost, Areeda and Turner suggest the substitution of average variable cost as a surrogate

66. A rough interpretation can be made of these post-entry costs of supply. Entry, if it occurs at all, involves supplying incremental product in the amount $Q_{\mathbf{T}}$ under each of the rules (given the assumptions of the model). The object of the dominant firm in each case is to react to entry in such a way that the entrant's profits are reduced to zero. This will occur if post-entry market price is driven down to $\mathbf{P}_{T}$, which requires that aggregate post-entry product in the amount $Q_{0}+Q_{x}$ be supplied. The dominant firm thus supplies post-entry product of $Q_{0}$ whichever rule is in effect. The reference coordinates $\left(P_{T}, Q_{0}\right)$ are therefore identical for each predatory pricing rule (in the sense that the curves $Q=Q$, $S R M C_{2}$, and $S R A C_{3}$ all must pass through this point). Given this common reference point, the relations among the cost curves all follow by construction.

67. The social costs of supplying $Q_{0}$ are the real costs incurred in the process. These include user costs of capital, but exclude depreciation of plant and equipment that is independent of utilization rates. Average costs include capital charges of both kinds, but average variable costs include only the former. 


\section{Predatory Pricing}

for marginal cost. ${ }^{68}$ Average variable cost is everywhere lower than average total cost. Hence, if the average variable cost rule were adopted the response function of the dominant firm would be flatter than under the average cost rule. Pre-entry output would be lower (hence pre-entry price would be higher) under the average variable cost rule. The average variable cost curve that passes through $\left(P_{\mathfrak{T}}, Q_{0}\right)$ corresponds to a smaller plant scale and higher average total costs (evaluated at $Q_{0}$ ) than is shown by the curve $S R A C_{3}{ }^{60}$ Hence, if the dominant firm chooses a plant that allows it to charge $\mathrm{P}_{\mathrm{T}}$ (and thus deter entry) while still meeting a test that price exceed average variable costs, the firm will produce less in the pre-entry period and its cost will

68. Areeda \& Turner, supra note 3, at 716-18, 733 .

69. These cost relations can be shown graphically as follows:

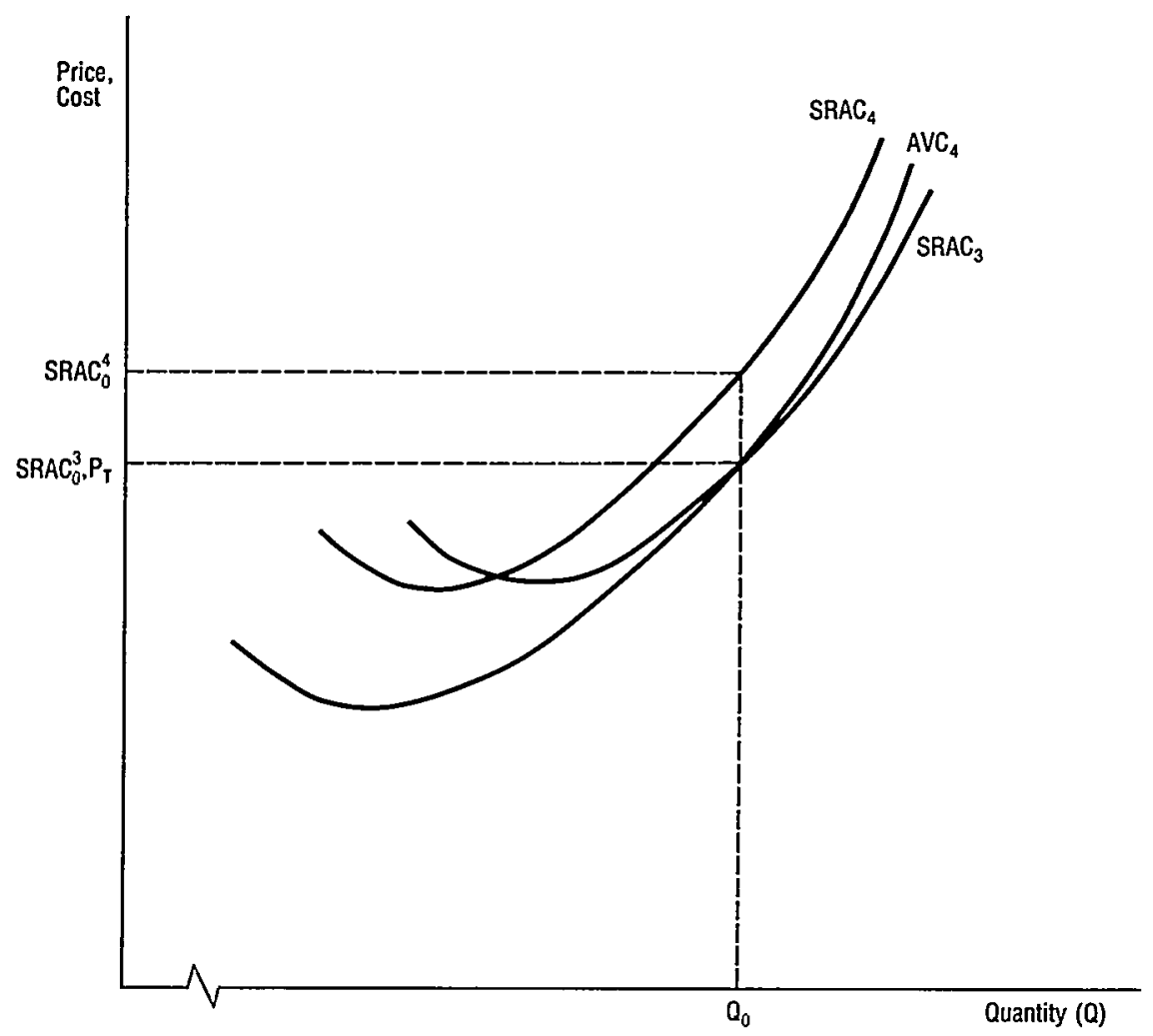

Note that for $A V C_{4}$ to pass through the point $\left(\mathrm{P}_{\mathrm{T}}, \mathrm{Q}_{\mathrm{O}}\right)$, as required, the corresponding short-run average cost curve $\left(S R A C_{4}\right)$ is displaced to the left of $S R A C_{3}$. Accordingly, the cost of supplying $Q_{0}$ if the cost curve is of type 4 exceeds that of supplying $Q_{0}$ if the cost curve is of type 3 instead. 
be higher in the post-entry period than under the other three rules. Altogether, the average variable cost rule, plausible though it appears, has the worst welfare properties of all.

\section{Information and Uncertainty}

The prospective entrant can form expectations relatively easily when the output restriction rule is in effect. The dominant firm may reduce output in response to entry. But the "worst" that it will do is hold output unchanged. Even recognizing that the rule allows for a trend adjustment of the maximum output, $\boldsymbol{Q}$, which will be necessary in a growing market, the maximum output allowed the firm will be relatively easy to establish.

Where either a marginal cost or average cost rule is in effect, however, the prospective entrant also needs to know the dominant firm's response curve ( $S R M C$ or $S R A C$ as the case may be). This is a much more demanding knowledge requirement and, since such cost curves can only be approximated, an additional estimating error appears in the prospective entrant's calculations, adding a further source of risk. These same cost estimation difficulties, moreover, complicate litigation and increase uncertainty if either of the cost-based rules is in effect because the court must ask whether lower-bound cost conditions were really violated. This can be very difficult to establish-as Cooper remarks ${ }^{70}$ and as both Areeda-Turner ${ }^{71}$ and Posner ${ }^{72}$ concede.

Finally, even if a potential entrant knew with certainty the dominant firm's response curve, the curve merely reflects a constraint. The constraint places a limit on the dominant firm's post-entry behavior, but does not uniquely determine it. Under the output restriction rule, the output of the dominant firm will either be reduced or remain unchanged. With either of the cost-based rules in effect, output may increase, decrease, or remain unchanged. The greater latitude for dominant firm reaction permitted by the cost-based rules introduces greater uncertainty for the potential entrant.

\section{Simplifying Assumptions}

Recall that three simplifying assumptions were introduced to facilitate modeling: the potential entrant and dominant firm were assumed to have access to the same long-run average cost curve; the dominant firm was assumed to choose a technology consistent with

70. Cooper, supra note 3 , at 438 .

71. Areeda \& Turner, supra note 3 , at 716-18, 733.

72. R. POSNER, supra note 3 , at 189-91. 
the long-run average cost curve; and the long-run average cost curve was assumed to be a step function. This section considers the welfare ramifications of relaxing these three assumptions.

The assumption of identical cost curves was a modeling convenience but may be at variance with the facts. To the extent that learning-bydoing yields operating cost savings or differential risks give rise to capital cost differences between new entrant and established firm, ${ }^{73}$ the new entrant will not have immediate access to the identical cost function as the dominant firm. So long, however, as these cost differences are no greater when the output restriction rule is in effect than under either of the cost-based rules, the ordering of rules will be unaffected. And arguably cost differences will be less under the output restriction rule since entry risk is greater under cost-based rules.

The assumption that the dominant firm chooses a technology consistent with the long-run average cost curve favors the cost-based rules. Suppose that the dominant firm is governed by the marginal cost predatory pricing rule. The issue that was suppressed is whether the dominant firm might select an inferior technology if this gives it access to a more "advantageous" response curve (in the sense that the result is higher pre-entry profits). The dominant firm's problem can be formulated as follows: from among the family of plant designs with short-run marginal cost curves passing through the coordinates $\left(P_{T}\right.$, $\mathrm{Q}_{0}$ ), choose the plant design that maximizes pre-entry profits. As shown in Figure 5, in these circumstances a plant design with a relatively flat average cost curve $\left(A C_{2}\right)$ may be preferred to the efficient plant design with a more steeply sloped cost curve $\left(A C_{1}\right){ }^{7^{4}}$ Given the greater flexibility to respond to entry afforded by the flat average cost curve, the dominant firm may realize greater profit in the pre-entry period by restricting output more than it otherwise would. ${ }^{75}$ Pre-entry output is smaller, and social welfare is reduced, if plant of type 2 rather than plant of type 1 were to be constructed.

73. See pp. 303.04 and notes 57 \& 59 supra.

74. For an early treatment of these types of cost curve choices in terms of risk and plant flexibility, see Stigler, Production and Distribution in the Short Run, $47 \mathrm{~J}$. Pol,ITICAL ECON. 305 (1939), reprinted in ReADings in THE Theory of Income Distribution 119 (IV. Fellner \& B. Haley eds. 1951).

75. As is cvident from the discussion of residual demand curves, see pp. 310-11 supra, a flatter cost curve always permits the dominant firm to make a greater post-entry output response if cost-based rules are in effect, ceteris paribus. But flatter (more flexible) cost curves can be realized only by sacrificing plant specialization. Inasmuch as a more specialized plant affords lower costs when the plant is operated at design capacity, the revenue benefits attributable to the greater pre-entry output reduction permitted by a more flexible plant are eventually offset by the greater costs implied by an unspecialized plant. 


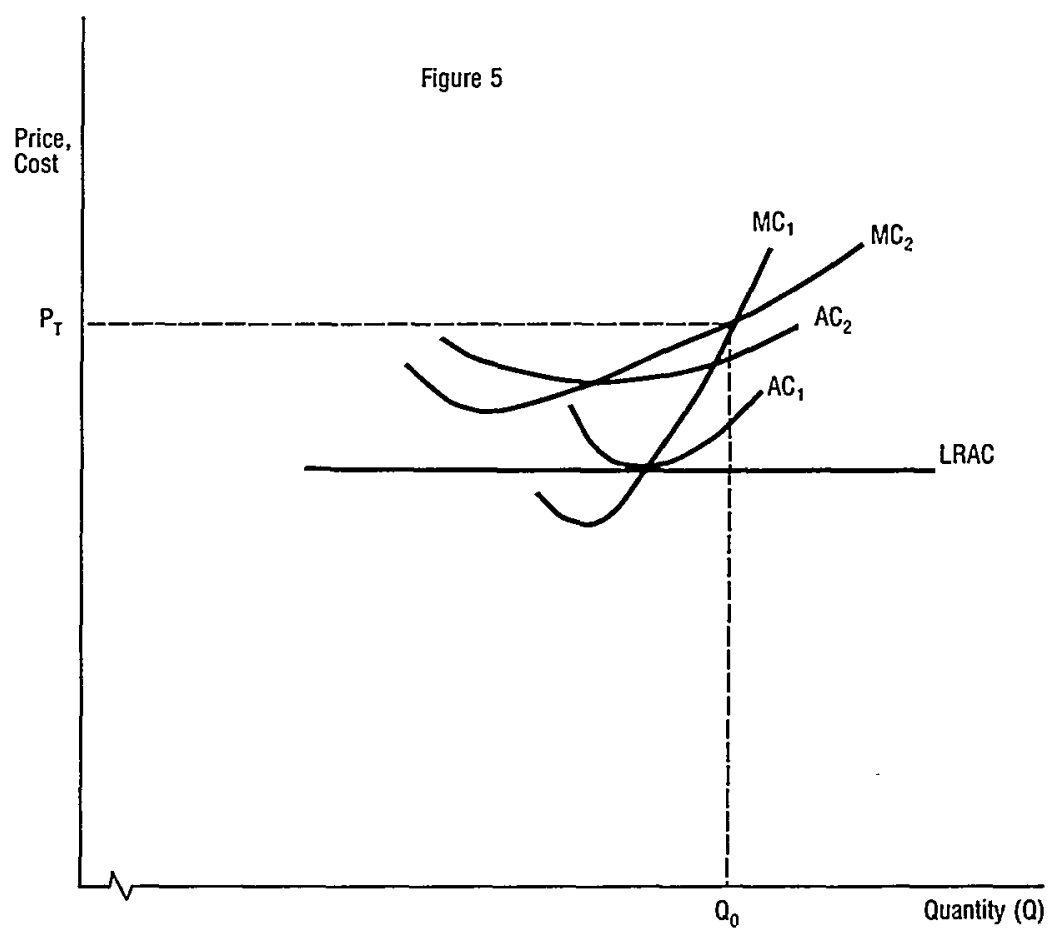

Plainly, however, this is a rather risky strategy. Should an entrant appear with requisite capacity at an efficient scale, the monopolist would find that his inefficient plant placed him at a competitive disadvantage. Accordingly, strategic selection of plant designs in which plants off of the long-run average cost curve are actively considered has been ignored. The tradeoff between pre-entry profits and postentry hazards was settled decisively by sacrificing the former in favor of strict avoidance of the latter. This is an arbitrary assumption. To the extent that dominant firms are prepared to run such risks, the welfare effects need to be taken into account. But the incentives to select inferior technologies, which plainly exist when cost-based rules are in effect, vanish if the output restriction rule is in effect. ${ }^{76}$ An inferior technology is attractive only if post-entry output expansion is permitted; the output restriction rule disallows this. The welfare advantages associated with the output restriction rule are thus reinforced when the assumption that dominant firms must choose plants on the long-run average cost curve is relaxed.

Consider finally the effect of relaxing the assumption that the long-

76. Conceivably the dominant firm will select a "flexible" plant for the reasons given by Stigler, supra note 74. But there are no response function incentives for the firm to do so under the output restriction rule. 
run average cost curve is a step function. The step function assumption is attractive because it is realistic ${ }^{i 7}$ and because it facilitates the analysis. The analytical advantage is that the residual demand curves, which vary with the predatory behavior rule in effect, have a common tangency at the point $\left(\mathrm{P}_{\mathrm{T}}, \mathrm{Q}_{\mathrm{T}}\right)$ under this assumption. ${ }^{78}$ Were the long-run average cost curve to decline smoothly throughout, the tangency would vary, there would no longer be a common dominant firm post-entry output of $Q_{0}$, and welfare effects would be more complicated to evaluate.

Given a smoothly declining average total cost curve, rules that cause flatter residual demand curves (as the cost-based rules do) will be tangent to the long-run average cost curve at a lower price and larger output. The pre-entry output of the dominant firm will be further reduced for cost-based rules than for the output restriction rule. Postentry output (of dominant firm and new entrant taken together), however, will be greater under the cost-based rules.

Although the pre-entry welfare advantages of the output restriction rule are unambiguously greater when the tangency point varies among the rules, the post-entry welfare effects may (but need not) favor the output restriction rule. A weighted average of these two effects would probably preserve the rule ordering, however, since entry (and hence post-entry adaptations) is presumably the exception in industries given to the type of strategic behavior investigated here. Thus the pre-entry effects are likely to dominate.

\section{Entry into Generational Equipment Industries}

The discussion has assumed that the commodity is in continuous production and that improvements in product and process are introduced gradually. The changes resulting from these improvements are assumed to be of degree rather than kind. Although some sales of the improved product will be to new customers, most of the sales will be to current users-to renew intermediate product inventories, to replace damaged or worn-out durable items, or to continue consuming nondurables.

Yet there are a few products for which simple renewal or replacement sales rarely occur. This is the case where new product embodies

77. The step function reflects the fact that discrete technologies become available at higher levels of output that are infeasible at all lower levels. Changes in kind cause discontinuities in long-run average cost curves, thus turning the continuous curve into a step function.

78. This is obviously arbitrary. For a large enough shift in the residual demand curve, tangency might not occur at the point $\left(\mathrm{P}_{\mathrm{T}}, \mathrm{Q}_{\mathrm{r}}\right)$, and a new technology would be adopted. 
significant technological improvements. Existing product is displaced by the superior technology; successor generations of product render the earlier model obsolete.

Consider in particular the case where the dominant firm introduces a new line of equipment and completes its production run before rivals imitate the line and offer substitute products. Assume that the product is durable and has several years of useful life before being displaced by a successor generation of equipment that embodies superior technology. Also assume that the product is initially leased rather than sold. What marketing behavior by the dominant firm shall be regarded as nonpredatory during the period between termination of production and the appearance of the new technology?

\section{A. Market Clearing at $\boldsymbol{Q}+\Delta$}

Let the stock of equipment produced by the dominant firm be $\boldsymbol{Q}$. Assume that the costs of leasing and servicing this stock are negligible and that the dominant firm is prepared to sell the entire stock at whatever nondiscriminatory price the market will bring. If no additional product appears, market price, denoted $\mathrm{P}(Q)$, is then $\mathrm{P}(Q)$, which corresponds to the intersection of the demand curve and the quantity $\boldsymbol{Q}$. Suppose, moreover, that the dominant firm places its entire stock on the market whatever the state of the market. ${ }^{70}$ The dominant firm effectively becomes a price taker. If demand is unchanged and new entrants bring incremental output of an amount $\Delta$ onto the market, market price will be given by $\mathrm{P}(Q+\Delta)$, which is less than $\mathbf{P}(Q)$.

When new entrants anticipate that the dominant firm will not take product off the market in the face of entry, entrants will have access only to the residual demand curve to the right of $\boldsymbol{Q}$. Additional product can be sold only by attracting new customers and selling more product to existing customers, the demands for both of which are represented by the portion of the demand curve to the right of $\boldsymbol{Q}$. Moreover, entrants' output decisions effectively determine price. The amount of product that they place on the market determines aggregate supply and hence market price. Entrants will presumably supply the amount of additional product that maximizes their profits given that they are optimizing with respect to the residual demand curve.

In Figure 6 , if the industry demand curve is $D_{1}$, then $D_{1}^{\prime}$ will be the residual demand curve and the entrant (or firm "imitating" the

79. That is, the entire stock is put on the market despite shifts in demand, new product supplied by entrants, or other factors. 


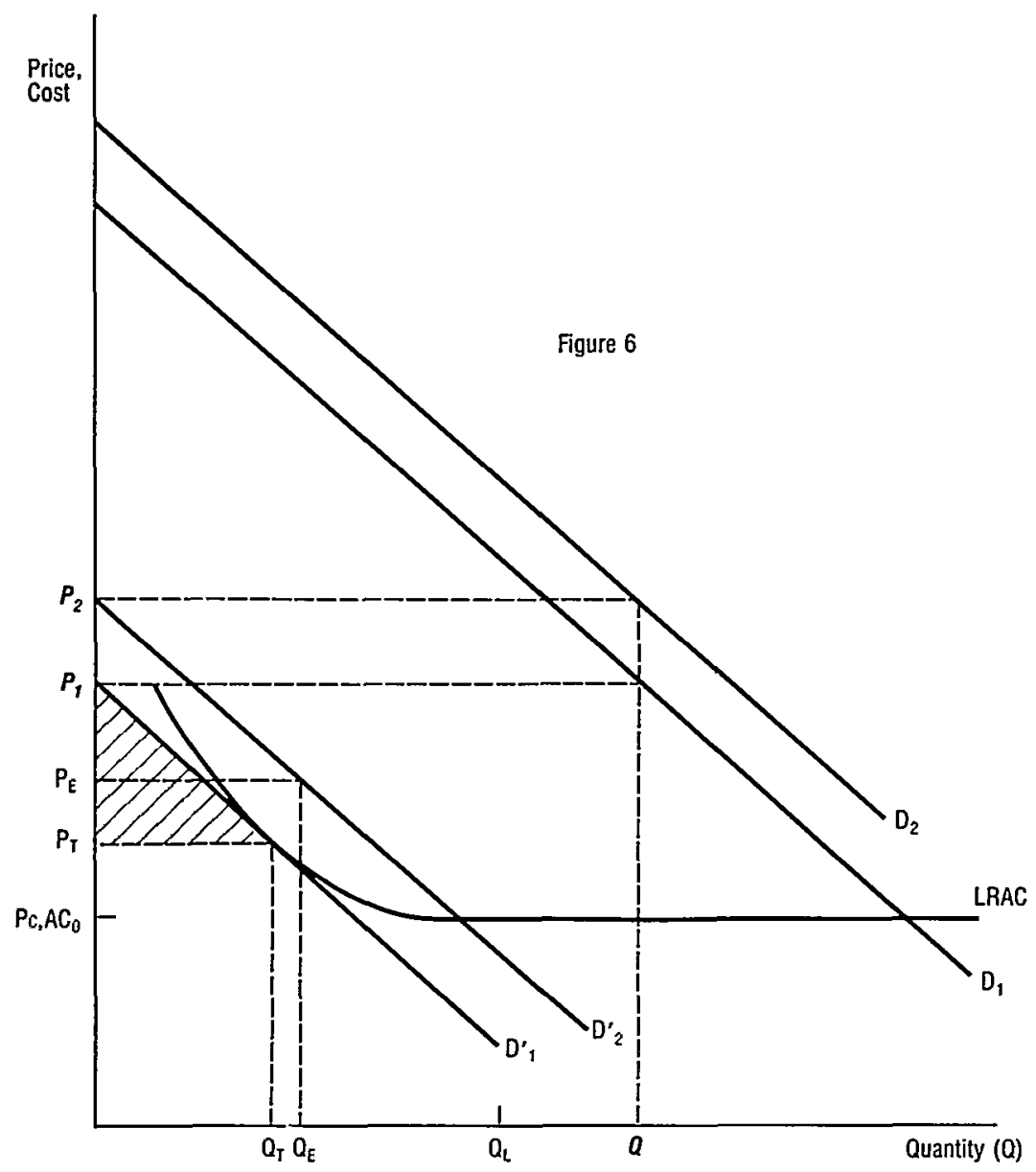

dominant firm's new generation of equipment) will be indifferent between producing zero output and producing $Q_{\mathrm{T}}$. There is, however, a welfare gain, shown by the shaded region, if the imitator produces $\mathrm{Q}_{\mathrm{T}}$ under these circumstances. The market price, to both dominant firm and imitator, will be $\mathrm{P}_{\mathrm{T}}$. If instead the market demand curve is $D_{2}$ and the dominant firm has discontinued production after the stock $Q$ has been completed, the residual demand curve will be $D_{2}^{\prime}$ and the entrant can earn positive profits by producing $Q_{\mathrm{E}}{ }^{80}$ in which case the price falls from $\boldsymbol{P}_{2}$ to $P_{E}$. Special rules that prevent the dominant firm from selling $\boldsymbol{Q}$ on whatever terms the market will bear have significant welfare implications if, as is commonly true of specialized equip-

80. $Q_{\mathrm{c}}$ is assumed to be the profit-maximizing output for the imitating firm. The entrant will earn positive profits on any output within the region where the residual demand curve, $D_{2}^{\prime}$, exceeds the long-run average cost curve. 
ment, the value of the dominant firm's stock of product is negligible in its best alternative use. Any rule requiring the dominant firm to maintain its price at pre-entry levels prevents utilization of product that can be used at zero social cost. Although price maintenance rules yield private gains to new entrants, social losses result.

Suppose, however, that a price maintenance rule is in effect and that the demand curve is $D_{2}$. Before entry the market-clearing price for the stock $\boldsymbol{Q}$ is $\boldsymbol{P}_{\mathbf{2}}$. The relevant demand curve for the new entrant is then a kinked demand curve that is horizontal at $\boldsymbol{P}_{2}$ between $\mathrm{O}$ and $Q$ and follows $D_{2}$ thereafter. The corresponding marginal revenue curve will have a discontinuity at $\boldsymbol{Q}$. Suppose, moreover, that the new entrant is not able to maximize its profits by equating marginal revenue and marginal cost because it has a capacity limit of $Q_{L}$ (where $\left.Q_{\mathrm{E}}<Q_{\mathrm{L}}<Q\right)$. If the new entrant then offers product at a price $\boldsymbol{P}_{2}-\varepsilon$, where $\varepsilon$ is a small number, while the dominant firm is constrained to offer product at the price $\boldsymbol{P}_{2}$, the entrant will sell $\mathrm{Q}_{\mathrm{L}}$ of product at an average social cost of $A C_{0}$ while the dominant firm will sell approximately $\mathbf{Q}-\mathrm{Q}_{\mathrm{L}}$ of the product at a social cost of zero. Essentially no additional product is sold, even though the aggregate stock of product available for sale is increased by $Q_{\mathrm{L}}$, since the dominant firm retires stock in an amount $Q_{\mathrm{L}}$ as a result of the price maintenance rule.

Absent a special justification for such a price maintenance rule, a waste of valuable resources plainly results, since without the price maintenance rule the dominant firm would sell its entire stock, $Q$, at zero social cost, and additional product in the amount $\mathrm{Q}_{\mathrm{E}}$ would come onto the market bringing incremental welfare gains. ${ }^{31}$ More generally, any rule, price maintenance or otherwise, that prevents the dominant firm from selling $Q$ at the prevailing market price is tantamount to a rule stipulating that some part of $Q$ be placed on the shelf or scrapped. Such rules waste goods having social value.

\section{B. Possible Exceptions}

Might there be countervailing considerations not yet taken into account that would justify a policy of forced retirement of assets? Two appear plausible. First, a dominant firm confronted with a price maintenance rule might be induced to produce and offer more product for sale in the pre-entry period. ${ }^{82}$ Pre-entry social gains would thereby

81. The incremental welfare gains are given by the area under the residual demand curve between the origin and $Q_{E}$ less the costs of supplying $Q_{E}$.

82. The dominant firm must form expectations about how much product new entrants will bring onto the market as a function of the pre-entry stock in order to optimize production. Presumably the amount of product supplied by entrants varies inversely with the stock of product supplied by the dominant firm. 
result, although this assumes that the dominant firm will still find it attractive to develop and produce a new generation of equipment under a $P=P$ rule. This last assumption is problematic. The magnitude of pre-entry gains must in any event be weighed against the previously described losses entailed by a post-entry price maintenance rule.

A second possible justification is the "infant firm" argument. The general infant firm argument would presumably take the following form: preventing the dominant firm from selling $\boldsymbol{Q}$ at the market price (for example, permitting it to sell only $\boldsymbol{Q}-\delta$ ) when new entry appears will permit entry to occur on a larger scale than would otherwise be feasible; entry at this larger scale is needed for the new entrant to become a qualified innovator (or earlier imitator) of original equipment; future period gains on successor generations of equipment would thus be realized if the dominant firm is constrained to hold its price at or near the pre-entry level (which effectively requires it to retire product). This is a rather bold argument that entrants may invoke in a self-serving way. Areeda and Turner have characterized arguments of this genre as "intrinsically speculative and indeterminate," and have argued that "[n]o suitable administrative rules could be formulated to give them recognition." 83 Although the argument may be valid in special circumstances, ${ }^{84}$ these are surely the exception and not the rule.

Besides being speculative, the claim that technological progress will be promoted by protecting infant firms does not establish that welfare gains result. Do the discounted future period benefits more than offset the immediate losses that involuntary asset retirement by the dominant firm would entail? Where the prospects for future gains from innovation are small or problematic, a policy of forced retirement of product in support of infant firms seems dubious.

Another disability is the cost of enforcing the rule. If a requirement of involuntary asset retirement is to be the exception rather than the rule, those industries considered to be exceptions must be identified in advance or dominant firms will not know how to behave lawfully. Identification of these exceptions will be difficult even at a single point in time, much less over time. Although specific investigation of dominant firm industries in national markets would be possible be-

83. Areeda \& Turner, supra note 16 , at 897 .

84. Conceivably an underdeveloped country might decide to impose special restraints on established multinational firms if, by assisting indigenous firms, the skills needed to hasten development would be promoted. System gains would thus offset the local losses caused by an infant industry rule. 
cause the number of such industries is relatively small, it would be impracticable to investigate and declare exceptions for the much larger number of local and regional geographic markets with dominant firms.

Finally, even if agreement could be reached in advance, a special predatory pricing rule for those industries declared to be exceptions is a questionable way of promoting greater pre-entry output or future technological progress. Alternative instruments for promoting competition and technological progress in these industries-including explicit subsidies, affirmative incentives for dominant firms to spin off technological ventures, ${ }^{85}$ or, possibly, dissolution ${ }^{86}$-are apt to be as or more effective.

A policy of involuntary asset retirement under circumstances of the kind described in this section is a dubious undertaking. At the very least, those responsible for public policy formation in this area should (I) recognize the hazards of declaring exceptions and (2) give serious consideration to other public policy alternatives for promoting the intended benefits.

\section{Voluntary Retirement of Product}

If regulation were costless, public policy would presumably require that the dominant firm sell its entire stock of product, $\boldsymbol{Q}$. Any policy permitting the dominant firm to retire stock voluntarily runs the risk of causing welfare losses. Valuable assets with significant social value could be shelved or scrapped. But if regulatory solutions are disfavored, the possibility that the dominant firm will voluntarily retire product in the face of new entry must be entertained. ${ }^{87}$

A policy requiring a dominant firm to sell its entire stock in the face of entry will probably be a redundant constraint-although dominant firms confronted with such a requirement may produce less than they otherwise would in the pre-entry period. Voluntary asset retirement by a dominant firm faced with entry is an accommodating posture. Entrants may interpret asset retirement as an invitation to make further inroads, with the result that the dominant firm will have to retire even more product to prevent price deterioration. Where accommodation is anticipated to lead to substantial output increases by

85. See O. Williamson, supra note 27 , at 192-207.

86. See id. at 223-26.

87. This is especially likely to occur if the demand for the product in the range $Q+\Delta$ is inelastic. It is sometimes argued that monopolists will never set price in the range where demand is inelastic. This ignores the fact, however, that dominant firms sometimes price with an eye to entry. Also, even if pre-entry demand elasticity exceeds unity, postentry demand elasticity (evaluated at $\boldsymbol{Q}+\Delta$ ) may be below unity. 
entrants, dominant firms may eschew a policy of voluntary asset retirement and instead sell $\boldsymbol{Q}$ at whatever price the market will bring.

\section{Predatory Pricing Among Established Rivals}

There are three cases in which predatory pricing may be directed at established rivals. The first involves price cutting by established firms in a mature, but nevertheless loosely disciplined, oligopoly. The second involves price cutting by firms in an industry still in the early stages of development. The third case is the use of promotional prices by firms attempting to enter a new market. Each poses distinctive problems.

\section{A. Loose Oligopoly}

The loose oligopoly condition can be further broken down into stable demand (or slow growth) and declining demand cases. In neither case do established firms have incentives to engage in the strategic prepositioning practiced by dominant firms or collusive oligopolists anticipating entry. Hence the concern that predatory pricing rules will influence pre-entry investment is irrelevant for loose oligopolies. Instead, cost-based rules are needed. The question then is what rule is appropriate for each condition.

\section{Stable Demand}

Any of a number of disturbances can upset pricing relationships among established oligopolists. For the most part, the ensuing pricecutting episodes do not occasion public policy concern. A predatory pricing issue arises only if price cutting persists and there is an indication that one or more firms is relying on a deep pocket in an effort to force the exit of some firms from the industry.

The appropriate test in such a situation is that prices should be remunerative. In the very short run this means that the price-cutting firm should never drop prices below average variable costs. An average variable cost test poses special hazards, however, if firms in the industry have different technologies. Firms that are more capital intensive will have lower average variable costs, ceteris paribus, since they have more fixed (nonvariable) capital costs. Since these firms may not be the most efficient firms in the industry, sustained low prices should be required to cover short-run average total costs. Where prices are maintained at low levels indefinitely, such prices should prospectively recover all costs in the long run.

Thus although a cost-based test is appropriate when there is sus- 
tained price cutting, neither short-run marginal cost nor its surrogate, average variable cost (which are the test criteria proposed by Areeda and Turner), is suggested. Rather, the relevant test is one of remunerative pricing. An average cost test both sorts out the efficiency of firms more accurately ${ }^{88}$ and poses fewer problems of estimation by litigants. The efficiency advantage is that low-cost firms that are either labor intensive (and thus have high variable costs) or lack deep pockets will not be jeopardized by an average total cost pricing test. Only high-cost firms will be forced to exit. The cost estimation advantage is that all costs are taken into consideration. This scarcely assures a determinate result, but much of the accounting discretion allowed by a short-run marginal or average variable cost test is nevertheless reduced.

\section{Declining Demand}

The declining industry is a special case. Objectively viewed, some firms will have to exit. Efficiency is served if those with high out-ofpocket costs are forced to go early. Firms with specialized plant and high fixed costs, but low out-of-pocket costs, will remain. Society gains because the firms that are earliest to exit are those with the highest opportunity costs. An average variable cost test is thus appropriate. ${ }^{80}$ It is noteworthy that the only case for which the Areeda and

88. Posner also makes this point, but not without considerable terminological confusion. R. Posner, supra note 3, at 192. Thus he objects to the Areeda-Turner short-run marginal cost test because it purportedly

ignores the fact that short-run marginal cost is lower than long-run marginal cost ... even when there is no excess capacity. In the short run, marginal cost does not include interest, rent, depreciation, and other overhead items, because they do not vary in the short run with the amount of output produced, but they are part of the long-run marginal cost of production, which is why a firm's short-run marginal cost

is normally lower than its long-run marginal cost. Id. at 191-92.

This last reflects confusion between average total costs and average variable costs on the one hand and long-run marginal costs and short-run marginal costs on the othor. See Scherer, Book Review, 86 Yale L.J. 974, 991 n.90 (1977). Posner's statement would be correct if average variable cost is substituted for short-run marginal cost whenever it appears and average total cost replaces long-run marginal cost. The statement is technically incorrect, however, as it reads. The relevant distinction between short-run marginal costs and long-run marginal costs is a temporal one. In the short run plant scale is fixcd. Producing successively more output from a fixed plant involves more intensive utilization of variable factors-multiple shifts may be introduced, scrappage rates may increase, scheduling problems and bottlenecks develop, etc.-with the result that the incremental cost of supplying the last unit easily becomes great and exceeds the cost of supplying this unit if plant scale were increased appropriately. Contrary to Posner, short-run marginal costs exceed long-run marginal costs at production levels that exceed design capacity. Sce G. Stigler, The Theory of Price 156-58 (3d ed. 1966); Viner, supra note 50.

89. This may be refined to require that price exceed short-run marginal costs as well. But this is a technical refinement, the operational significance of which may be questioned. 
Turner tests and those proposed here agree is the very special case of a declining industry.

\section{B. Early Stage Growth Industries}

Perhaps the most difficult case to assess is the industry that is still in an early stage of development. Demand is growing rapidly, often accompanied by technological improvements of a significant kind. Firms that entered early and were profitable under excess demand conditions, but are unable to realize cost economies or maintain the progressive pace, may have to be "shaken out." This is a painful process and may occasion predatory pricing suits. The question is what criteria to apply.

The basic dilemma is that although firms with deep pockets may entertain dominant-firm aspirations and may attempt to accelerate the demise of small rivals by resorting to predatory pricing, there is a great risk that-since truth is especially difficult to ascertain in the early stages of growth-unmeritorious charges of predatory pricing will be brought by marginal firms. Lest the forces of economic natural selection be held in check by the application of rules designed to deal with more settled states of affairs, a double test is proposed. First, a remunerative pricing test should be applied to the would-be dominant firm. Since costs may fall rapidly in the early stages of an industry's growth, a price should be assumed to be nonremunerative only if it is below current costs as reduced to account for future unit cost reductions. ${ }^{00}$ The second part of the test would require that the plaintiff demonstrate that it can attain cost levels competitive with the defendant firm's costs. A requirement of current cost equivalence between the would-be dominant firm and the plaintiff would be too severe, since nondominant firms may become effective competitors if given a reasonable chance. Firms experiencing substantially higher costs relative to other small rivals should be disqualified from bringing predatory pricing suits. ${ }^{91}$

90. This is to allow for the possibility that costs may be falling rapidly as a result of (static) scale and (dynamic) learning-by-doing cconomies. If today's price does not cover yesterday's costs but exceeds tomorrow's, how is the price to be evaluated? Even a profitmaximizing monopolist might set current price below current costs if future costs (and possibly future demand) are beneficially affected. Surely, however, a price is presumptively nonremunerative if it is below current costs as reduced by the discounted value of future unit cost reductions attributable to incremental current supply.

91. A variant that may arise in demonstrating cost effectiveness concerns the case where the plaintiff procures an essential component from a vertically integrated rival. Achieving cost parity may then be complicated if either the internal transfer price and the market price of the component differ or if supply reliability differs between internal 


\section{Promotional Pricing}

Charges of predatory behavior are normally brought by entrants rather than established firms, but local firms with large market shares sometimes complain of predatory pricing when multimarket firms attempt to enter their territory. Utah Pie Co. v. Continental Baking Co. ${ }^{92}$ is a conspicuous example. Promotional pricing thus raises the question: should a new entrant be allowed to stage a promotional campaign that violates the cost-recovery test?93

Areeda and Turner characterize a promotional price as

a temporary, low price designed to induce patronage with the expectation that the customer will continue purchasing the product in the future at a higher [presumably cost-recovering] price. The promotional price may be below cost and is most easily illustrated by the seller who gives his product away without charge to some or all would-be customers. ${ }^{9 \pm}$

Such promotions may be the only effective way to overcome customer habit in industries where the product is differentiated by manufacturers. It is widely conceded that a promotional pricing exception may be warranted for products that are not, or are not perceived to be, homogeneous..$^{95}$

Although a promotional pricing exception would relieve the entrant of the need to satisfy a remunerative pricing test from the very outset,

and external users. Inasmuch as the object is to sort on efficiency, both nonintegrated and integrated firms need be evaluated on comparable terms.

This assumes that the nonintegrated firm is prepared to make firm contracts with the integrated supplier. It is unrealistic to expect delivery in spot markets on terms that are equivalent (in price and regularity of delivery) to those that the integrated firm makes when product is transferred between internal divisions.

Furthermore, the integrated firm is not required to transfer products between divisions on market terms. To the extent that it does not and cost parity becomes an issue in litigation, an adjustment is plainly warranted for evaluative purposes.

92. 386 U.S. 685 (1967). For discussions, see R. PosNER, supra note 3, at 194; Areeda \& Turner, supra note 3 , at $726-27$.

93. Two caveats are warranted. First, the industry may experience an unanticipated fall in demand, in which case full-cost recovery may be temporarily infeasible. Second, the relevant costs for the entrant are those that will obtain after allowance has been made for unusual start-up expenses for administration, manufacturing, and distribution (though possibly not promotion).

94. Areeda \& Turner, supra note 3 , at 713 .

95. For a thoughtful discussion of promotional pricing and admissible dominant reactions thereto, see Areeda \& Turner, supra note 3, at 713-16. Cooper also notes that below-cost pricing for promotional purposes warrants an exception. Cooper, supra note 3 , at 437 .

It should also be recognized, however, that product differentiation complicates the problems of welfare evaluation enormously. Consumers may or may not benefit by the additional product variety that an entrant offers. The discussion of promotional pricing in the predatory pricing literature presumes that greater variety is beneficial. The presumption is followed here. 
such relief would be strictly temporary. The time limits on a promotional pricing effort would vary with the product and would require marketing expertise to establish. Only a few rough guidelines for a promotional pricing exception will be offered here. First, promotional prices to industrial users should rarely be necessary (a few "demonstration" sales, perhaps, excepted). Appeal on the basis of the merits of the product should ordinarily be feasible from the outset. Second, promotional pricing for consumer durables is a doubtful undertaking, since repurchase will not occur for some time and imitation is apt to be a lagged and uncertain process. Consumer nondurables thus appear to be the area where promotional pricing is apt to be most attractive. The allowable length of a promotional pricing campaign for consumer nondurables should vary directly with the expected shelf life of the item. This may vary from a few weeks to, perhaps, a few months. But in no case should entrants expect to be able to effect massive market dislocations under the aegis of below-cost promotional pricing. ${ }^{96}$ Only competition on the merits would warrant this; continued supply at a price below cost may be regarded as an indication of predatory intent on the part of the entrant and is presumptively unlawful.

\section{Recent Cases and Commentary}

Two types of predatory pricing have been distinguished in this article. One involves predatory pricing in relation to new entry. The basic model, set out in Parts I and II, applies to products supplied continuously. This model was then extended in Part III to consider generational equipment industries. The second type involves predatory pricing directed against established rivals. The loose oligopoly (in both steady-state and declining industries), growth industry, and promotional pricing conditions each warrant separate treatment within this category. These were examined in Part IV. Three cases are examined here, illustrating four of these five conditions (omitting the growth industry situation).

\section{A. Rivalry Among Established Firms: Loose Oligopoly}

The recent case of Hanson $v$. Shell Oil Co. ${ }^{97}$ was a challenge to predatory pricing in a loose oligopoly. Hanson argued that in 1961

96. As Commissioner Elman observed when the Clorox case was before the FTC, a dominant firm "might tolerate the obtaining of a small foothold by a new entrant, but [it] can hardly [be expected to] sit by while a large share of the market is absorbed by the newcomer." Procter \& Gamble Co., 63 F.T.C. 1534, 1552 (1963), rev'd, 358 F.2d 74 (6th Cir. 1966), rev'd and remanded, 386 U.S. 568 (1967).

97. 541 F.2d 1352 (9th Cir. 1976). 
Shell began a program to recover lost market shares in certain southwestern states, where Shell's market share was about ten percent, ${ }^{18}$ by engaging in unlawful price competition. ${ }^{99}$ The Ninth Circuit observed that "Hanson presented no evidence which would suggest that the 'specific intent' to monopolize existed." 100 But the court took the argument further. Citing Areeda and Turner, the court held:

To demonstrate predation, Hanson had to show that the prices charged by Shell were such that Shell was foregoing present profits in order to create a market position in which it could charge enough to obtain supra-normal profits and recoup its present losses. This could be shown by evidence that Shell was selling its gasoline at below marginal cost or, because marginal cost is often impossible to ascertain, below average variable costs. ${ }^{101}$

The court further counseled that predatory pricing claims should not be upheld when they are used in a protectionist manner:

The antitrust laws were not intended, and may not be used, to require businesses to price their products at unreasonably high prices (which penalize the consumer) so that less efficient competitors can stay in business. The Sherman Act is not a subsidy for inefficiency. Hanson's failure to show that Shell's prices were below its marginal or average variable cost was a failure as a matter of law to present a prima facie case under $\S 2 .{ }^{102}$

The possibility that the antitrust laws can be used in a protectionist way to discourage price rivalry was plainly recognized by the court and equally plainly rejected. Although the court's reliance on an average variable cost test was inappropriate considering the duration of the pricing conduct, ${ }^{103}$ a cost-based test is necessary in a loose oligopoly to ascertain whether predation is present and, of equal importance, to prevent the predatory pricing law from being used as a shelter for inefficiency. In steady growth industries such as in Hanson, predatory pricing can be identified as sustained pricing below average total cost.

98. Id. at 1360 .

99. Id. at 1355 .

100. Id. at 1358 .

101. Id. (footnote omitted).

102. Id. at 1358-59 (footnote omitted).

103. As pointed out above, see pp. 321-22 supra, an average variable cost test does not adequately sort out the relative efficiency of firms with differing intensities of fixed assets. 


\section{B. New Entry: Standardized Product and Promotional Pricing}

Purex Corp. v. Procter of Gamble Co. ${ }^{104}$ illustrates the issues that arise when new entry is attempted in a standardized product industry. The Purex complaint raised a number of issues, including an allegation that Procter \& Gamble (P\&G)-Clorox had unlawfully encroached on Purex territories along the West Coast, but the "conclusive" indication that Clorox engaged in predatory behavior involved its response to the Purex entry in Erie, Pennsylvania. ${ }^{105}$ Inasmuch as Purex was a new entrant into this geographic market and the product in question was a consumer nondurable, Purex was presumably entitled to the temporary latitude afforded promotional pricing. And indeed Purex did use special promotions to launch its entry into this market.

104. 419 F. Supp. 931 (C.D. Cal. 1976). The district court's decision was part of a long litigation precipitated by Procter \& Gamble's (P\&G) acquisition in 1957 of the Clorox Chemical Company, makers of Clorox bleach. Id. at 933. The Federal Trade Commission ruled that the acquisition acted "to foreclose effective competition in the industry" and thus violated $\$ 7$ of the Clayton Act, 15 U.S.C. $\$ 18$ (1970). Procter \& Gamble Co., 63 F.T.C. 1465, 1569 (1963), rev'd, 358 F.2d 74 (6th Cir. 1966), rev'd and remanded, 386 U.S. 568 (1967). The Commission ordered P\&G to divest itself of Clorox within one year of the final order. Id, at 1585.87 . The Sixth Circuit set aside the Commission's order, Procter \& Gamble v. FTC, 358 F.2d 74 (6th Cir. 1966), rev'd and remanded, 386 U.S. 568 (1967), but the Supreme Court reinstated the decree. FTC v. Procter \& Gamble Co., 386 U.S. 568 (1967). As a result, in 1969 Procter \& Gamble was forced to divest itself of Clorox. 419 F. Supp. at 933.

Purex, Clorox's leading competitor in the bleach business, then brought a private treble damage suit under $\$ 4$ of the Clayton Act, I5 U.S.C. $\$ 15$ (1970), against P\&.G and P\&G's wholly owned subsidiary, the Clorox Company. $419 \mathrm{~F}$. Supp. at 933 . Purex alleged that P\&:G and Clorox had violated not only $\$ 7$ of the Clayton Act (the issue previously determined by the Supreme Court), but also sections 1 and 2 of the Sherman Act, 15 U.S.C. $\$ \$ 1,2$ (Supp. V 1975). The district court held that the Supreme Court's adjudication of the $\$ 7$ violation only established that the effect of the P\&G-Clorox merger " 'may be substantially" to lessen competition, or to tend to create a monopoly. " $419 \mathrm{~F}$. Supp. at 933 (quoting Clayton Act $\$ 7,15$ U.S.C. $\$ 18(1970)$ ) (emphasis supplied by court). Since a plaintiff in a $\$ 4$ treble damage action must show that he is "injured in his business .. . by reason of anything forbidden in the antitrust laws," 15 U.S.C. $\$ 15$ (1970), the court held that Purex had to show actual injury in addition to violation of $\$ 7.419 \mathrm{~F}$. Supp. at 934 .

Thus the court's opinion considered almost exclusively the issue whether the admitted $\$ 7$ violation, the P\&G-Clorox merger, caused actual damage to Purex. P\&.G-Clorox's conduct in the Erie market, see note 105 infra, only went to the issue whether Purex was damaged by actions Clorox could not have undertaken absent the merger. Id. at 941-42. The consideration of the alleged Sherman Act $\$ 2,15$ U.S.C. $\$ 2$ (Supp. V 1975), violation was relegated to two paragraphs at the end of the opinion. This does not affect the analysis in text since the court's discussion of the Erie incident, $419 \mathrm{~F}$. Supp. at 940-42, addressed itself to P\&G-Clorox's alleged "anticompetitive predatory practice designed to prevent a new competitor from getting a foothold in the [Erie] market." Id. at 940 .

105. 419 F. Supp. at 940-42. Irwin Stelzer, an expert witness for Purex, testified on cross-examination as follows: "I focused really on Erie .... [T] That was considered the terrific example of what dominant firms shouldn't be allowed to do." Trial Transcript at 2726-A. 
It was not alleged that these promotions were excessive; ${ }^{106}$ the only litigated issue was whether the response by Clorox was unlawful.

Purex took several positions on the predatory pricing claim, one of which was that Clorox should not be permitted to charge a price or incur promotional expenses that yield a net loss. ${ }^{107}$ The more basic question under the output restriction rule, however, is whether Clorox increased its sales in response to the Purex incursion. If Clorox had increased its sales of bleach above its accustomed volume, a presumption that this was a contingent response expressly designed to defeat entry would be warranted. Without such an increase, Clorox could be presumed instead to be conducting business at a steady level that would continue, entry or not. ${ }^{108}$

In addition to a remunerative pricing test, Purex also took the position that dominant firms (Clorox had a pre-entry market share in Erie in excess of sixty percent) have an obligation to accommodate entry. ${ }^{109}$ Since bleach does not lend itself to product innovations of a significant kind and Purex was a well-established producer of bleach in other geographic areas, no infant firm argument for the protection of Purex can reasonably be made. Rather, the argument reduces to a naked theory of umbrella pricing-in order to ensure the viability of a new entrant, the dominant firm is expected to maintain price. Since Purex was bringing additional (and substantially identical) product onto the market, P\&G-Clorox would evidently be required to reduce output in an offsetting amount, in order to maintain price, under the theory of competition advocated by Purex. That the new entrant may be a high-cost supplier or that the dominant firm will hold excess capacity in these circumstances are evidently of no account. This approach is ill-advised. It makes the easy but egregious mistake of protecting competitors rather than competition. ${ }^{110}$

106. But the size of Purex's promotional expenditures was at issue in the case. Purex apparently spent over $\$ 3.00$ per case of bleach sold on advertising and coupon discounts, while Clorox responded with expenditures and price reductions of about $\$ .90$ per case. 419 F. Supp. at 940 . The court noted that it is an accepted principle in the business community "that an established firm may use all fair means to protect its market," and found "nothing reprehensible or anticompetitive in the Clorox response" because "an unusually large attack may be expected to elicit a comparable response." Id. at 941. The court did not, however, address the lawfulness of the response in terms of either output or cost. Under the proposed criterion a $Q \leq Q$ test would have been appropriate.

107. Plaintiff's Opening Brief, Part II, at 183-85.

108. Clorox prices during the introductory interval when the $Q \leq Q$ constraint is in effect should, of course, cover its average variable costs.

109. These views are set out in remarks made by Alfred R. Oxenfeldt, an expert witness for Purex. Trial Transcript at 2452-53. This testimony was summarized by the plaintiff's attorneys as holding that "a newcomer must be given a chance to get established before the dominant firm responds." Plaintiff's Opening Brief, Part II, at 183.

110. Note that the output restriction rule is not an umbrella rule. It is sometimes mistakenly argued that the rule $Q \leq \boldsymbol{Q}$ is essentially equivalent to the rule $P \geq P$, where the 


\section{New Entry: Generational Equipment}

Telex Corp. v. International Business Machines Corp.111 illustrates the issues that arise when an entrant offers a product with a short life cycle by imitating the design of a device for which the dominant firm has discontinued production. ${ }^{112}$ Again, although a number of conduct matters were raised in the Telex case, ${ }^{113}$ the basic issue was the existence of predatory pricing. Although it oversimplifies, I will take it as given that (1) IBM's production of the computer peripheral device in question was terminated before entry appeared ${ }^{114}$ and (2) the device

latter is plainly a price umbrella rule. This purportedly follows since price and quantity are inversely related through the demand function (as price increases, less of the product is demanded).

The error arises over a confusion between firm and market conditions. The output restriction rule applies to the dominant firm. But if the output of the dominant firm is unchanged $(Q=Q)$ and the entrant brings the quantity $\Delta$ onto the market, the dominant firm must reduce its output in response to entry if it is to hold its price unchanged. In a market for a homogeneous product, the post-entry output of the dominant firm will be $Q-\Delta$ if the entrant supplies $\Delta$ and the $P=P$ rule is in effect. Thus under the $P=P$ rule the dominant firm makes a place for the entrant, while under the $Q \leq Q$ rule the entrant must make a place for himself if the dominant firm refuses to be conciliatory.

111. 367 F. Supp. 258 (N.D. Okla. 1973), aff'd in part and rev'd and remanded in part, 510 F.2d 894 (10th Cir. 1975).

112. It is not entirely clear from a reading of Judge Christensen's opinion in Telex whether or not IBM's production of disk drives was fully completed when IBM cut its price. Also, the price cut was selective rather than general. IBM was experiencing increasing competition for its 2314 disk drive from plug compatible substitutes (including the Telex 5314 disk drive). Rather than cutting the price on all $2314 \mathrm{~s}$ or allowing 2314s returned to IBM because of plug compatible competition to accumulate in storage, IBM decided to reconfigure the 2314 , adding certain control functions, and market the resulting 2319.A subsystem at a reduced price. A two-price system thus resulted: IBM maintained the price on those 2314 subsystems for which customers were willing to renew leases, while at the same time reducing the inroads made by plug compatible peripherals by marketing the $2319 \mathrm{~A}$ at a lower price. Telex Corp. v. International Business Machs. Corp., 367 F. Supp. at 291-96.

The assumption for the purposes of this analysis is that IBM had essentially completed production of the 2314 prior to the price reduction and that the cost of reconfiguring returned 2314s and adding control functions was a small fraction of the original manufacturing cost. Inasmuch as new plug compatible peripherals are designed to complement successive generations of computers, and given the assumptions stated above, the generational equipment model in Part III would appear to be applicable. (If the facts should turn out to contradict the assumptions in significant degree, however, a further analysis of the economic implications beyond those set out here would be warranted.)

113. The district court found IBM guilty of monopolization and attempting to monopolize in five specific respects:

1. The announcement and institution of the $2319 \mathrm{~A}$ disc storage facility in September 1970.

2. The announcement of the 2319B disc storage facility in December 1970 .

3. The announcement of the Fixed Term Plan long-term leasing program in May 1971.

4. The announcement and implementation of the Extended Term Plan, which was also a leasing plan, in March 1972.

5. IBM's pricing policies with regard to its memory products during 1970 and 1971 . Telex Corp. v. International Business Machs. Corp., 510 F.2d 894, 900 (10th Cir. 1975), aff'g in part and rev'g in part, 367 F. Supp. 258 (N.D. Okla. 1973).

114. See note 112 supra. 
had negligible value in its best alternative (nonperipheral) use. The question facing the courts was what pricing latitude should IBM (and other dominant firms similarly situated) be permitted in the face of entry by firms like Telex.

The welfare analysis of Part III discloses that, leaving aside infant firm issues, IBM should lease its entire stock of completed product $(\boldsymbol{Q})$ at whatever price would clear the market. New entrants would invariably prefer that dominant firms be required to maintain their prices, because umbrella pricing facilitates easy entry. The misallocative effects of such pricing, however, argue against the adoption of an umbrella rule. Insisting that established firms must maintain their pre-entry prices until entrants are thought to be well established, despite the consequences of equipment retirement, comes perilously close to arguing that, whatever the efficiency consequences, more firms are always preferred to fewer in dominant firm industries.

Might an infant firm exception be warranted? Technological innovation is an important feature of the electronic data processing industry. Suppose, arguendo, that alternative antitrust instruments ${ }^{115}$ are unavailable for promoting technological progress. Assume, moreover, that dominant firms receive adequate advance notification, and hence are aware of the bounds of lawful behavior. Three factors must be assessed to determine whether an exception is warranted. First, had Telex (or other peripheral manufacturers) made significant technological innovations? Second, are there structural factors that incline such firms to be leaders or followers? And third, if the answers to either of these questions disclose actual or potential leadership, would the gains from innovation be significant?

A complete answer to each of these questions is beyond the scope of this article, but a tentative evaluation is possible. The record in Telex indicates that Telex had mainly been a follower. ${ }^{116}$ Also, there are structural reasons to believe that this may have been the "natural" posture for peripheral manufacturers to adopt. ${ }^{117}$ Even if an argument

115. See p. 320 supra.

116. See the chronology of product introductions by IBM and Telex in Telex Corp. v. International Business Machs. Corp., 367 F. Supp. 258, 271-72 (N.D. Okla. 1973), aff'd in part and rev'd in part, 510 F.2d 894 (10th Cir. 1975).

117. The main frame manufacturers originate successive generations of new central processing units. Compatible peripherals are usually designed in the process. Leadership in peripheral design thus accrues naturally to firms responsible for state-of-the-art advances in central processing units. Furthermore, "entry was initially easy for peripheral equipment manufacturers because they could choose to copy only proven successful products." Telex Corp. v. International Business Machs. Corp., 367 F. Supp. at 286. Considerably more detailed knowledge of the industry is needed, however, before these issues can be settled definitively. 
could be made that imitators have technological leadership potential, this does not establish that welfare gains will be realized by requiring dominant firms to maintain price when confronted with entry. Such an involuntary asset retirement policy yields net welfare gains only if the discounted future benefits of such a policy exceed the immediate welfare losses. The issues in Telex were never addressed in these terms.

\section{Rules of Law: Prior and Proposed}

Areeda and Turner conclude their examination of the predatory pricing issue by proposing a series of rules, the most relevant of which are the following:

1. ....

(b) A price at or above average cost should be deemed nonpredatory even though not profit maximizing in the short run. (c) A price at or above reasonably anticipated shortrun marginal and average variable costs should be deemed nonpredatory even though not loss-minimizing in the short run.

2. Recognizing that marginal cost data are typically unavailable, we conclude that:

(a) A price at or above reasonably anticipated average variable cost should be conclusively presumed lawful.

(b) A price below reasonably anticipated average variable cost should be conclusively presumed unlawful..118

The Areeda-Turner rules do not distinguish predatory pricing in response to entry and predatory behavior among established firms. This distinction is basic; the rules of law proposed below expressly recognize it. The basic Areeda-Turner rules are formulated as marginal cost pricing tests, although Areeda and Turner concede that marginal cost is difficult to estimate and therefore offer average variable cost tests as an alternative. The rules proposed below eschew reliance on marginal costs.

\section{A. Entry}

The merits of the predatory pricing rules proposed below turn jointly on the efficiency arguments developed in earlier sections of this article and on the fairness attributes discussed in Part VII, which follows. Some perspective on the rules may nevertheless be gained by a brief recapitulation of their properties:

118. Areeda \& Turner, supra note 3, at 732-33. 
(a) the output restriction rule, even without an accompanying remunerative pricing test, represents a relatively severe restraint-certainly more severe than cost-based rules that permit dominant firms to offer contingent product in response to entry;

(b) the remote possibility that the output restraint will not by itself preclude nonremunerative pricing in the immediate post-entry period can be forestalled by additionally stipulating that the dominant firm shall not price below its average variable costs; ${ }^{110}$

(c) although the dominant firm is relieved of the output restriction when the initial (eighteen month) restraint period has expired, it is simultaneously subjected to an average total cost remunerative pricing test, which assures that deep pocket considerations will not influence viability in the long run;

(d) finally, promotional pricing exceptions aside, new entrants face two-stage remunerative pricing tests identical to those set out in (b) and (c) above. ${ }^{120}$

119. The argument that marginal cost should be the appropriate lower bound on prices is rejected for three reasons. First, the purported allocative efficiency benefits of marginal cost pricing are problematic in the short run. See pp. $287-92$ supra. Second, even assuming that marginal cost could be estimated to the satisfaction of the litigants, involving the courts in a marginal cost pricing test implies using the antitrust laws to effect fine tuning. This is an undertaking of dubious merit. See note 16 supra. Third, the operationality of a marginal cost pricing test is seriously in question. See note 124 supra.

120. As indicated, see p. 325 supra, entrants should not expect to effect massive market dislocations as part of a promotional entry effort. The special latitude afforded promotional pricing is merely intended to facilitate initial acceptance. Thereafter, a remunerative pricing test should apply.

It should be recognized that any entry effort-promotional or not-that combines a capital intensive technology (and hence low average variable costs) with deep pockets poses a potential difficulty. Conceivably, the entrant could offer product in the immediate post-entry period on terms that fully satisfy the remunerative pricing terms specified in rule 2.1, see p. 337 infra, while the dominant firm, with a less intensive technology, would be unable at the same price to recover its average variable costs. Lest the spirit of the remunerative pricing rules be abused (with counterproductive consequences), entrants attempting to exploit such average variable cost differences should be required to demonstrate that their cost advantages hold with respect to average total cost as well. If the latter test is failed, intermediate-term pricing at a level not less than that of the minimum average variable costs of the dominant firm could be stipulated. The viability of otherwise efficient dominant firms during the early post-entry period would not, therefore, be jeopardized.

The case can be made that new entrants should be granted a learning curve exception of the kind discussed in note 90 supra. The problem with this is that the necessary cost projections are difficult to make. Accordingly, there is a serious risk that new entrants (large or small) will abuse any such provision. I am inclined for this reason to restrict learning curve adjustment to early growth stage industries.

Although the issues addressed in this footnote are mainly of hypothetical (rather than operational) interest, it is noteworthy that the rules treat strategic behavior by dominant firms and entrants similarly: both are held to be objectionable. A restraint on ad- 


\section{Predatory Pricing}

\section{Lawful Behavior}

\subsection{Short Run: $Q \leq \boldsymbol{Q}$}

When dominant firms reduce their output or hold their (demand adjusted $)^{121}$ output unchanged in the face of new entry they shall be deemed to be behaving in a nonpredatory way provided that the resulting market price is not less than average variable cost. ${ }^{122}$

missible entry behavior is thus indicated where an entrant with a deep pocket and the requisite capital intensive technology attempts to subvert average variable cost pricing rules with a strategic purpose.

121. See pp. 305-06 \& note 33 supra for a discussion of demand adjustment.

122. A graphical display may be instructive. The short-run cost curves drawn below show the average total, average variable, and corresponding marginal costs of the dominant firm. The dominant firm is assumed initially to be producing at $Q_{0}$ and selling at a price $P_{0}$. When entry occurs, the dominant firm is permitted under the proposed rules to continue production at $Q_{0}$ provided that the resulting market price exdeeds $P_{\mathrm{Y}}$. If it does not, he must reduce output. If at $\mathrm{Qx}$ the price still does not cover his costs, production will presumably be discontinued (since out-of-pocket costs exceed revenues). This last outcome is doubtful, however, since inability to cover minimum average variable costs implies either massive inefficiency on the part of the dominant firm or a strong likelihood that the new entrant is behaving in a predatory way (in which event the dominant firm is entitled to relief).

Note that whereas an average variable cost proviso is actually more permissive than a marginal cost pricing test ( $A V C$ is less than $S R M C$ in the relevant region $Q_{\mathrm{x}}$ to $\mathrm{Q}_{0}$ ), the output restrictions severely limit the range of action open to the dominant firm. Areeda and Turner's (surrogate) rules would allow the dominant firm to expand beyond Qo provided that prices recovered variable costs.

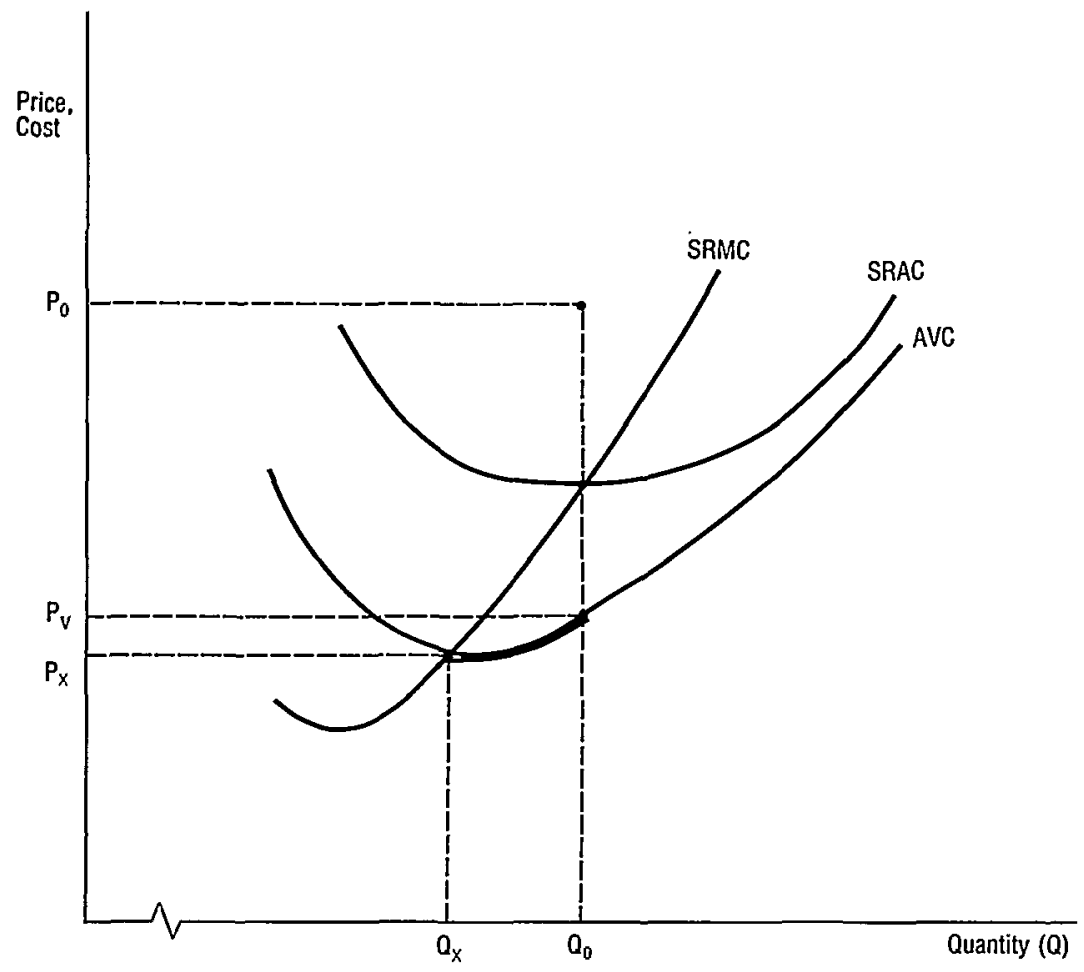




\subsection{Long Run}

Prices calculated to recover full costs over a sustained production interval, during which plant renewal and other expenses come due, will be deemed nonpredatory. ${ }^{123}$

The rationale for rule 1.2 is that output limits placed on the dominant firm in the short run are less easily justified, and more difficult to police, in the long run. When entrants have incurred the threshold costs of entry and have not been rendered nonviable by short-run strategic responses of dominant firms, they ought to be well positioned to participate in industry growth, achieve cost economies, and compete effectively. The restrictions on output expansion stipulated in rule 1.1 above are accordingly relaxed in the long run and are supplanted by an average total cost remunerative pricing rule.

\section{Unlawful Behavior}

\subsection{Short Run: Q $>\boldsymbol{Q}$}

Dominant firms that expand their (demand adjusted) output in the face of new entry will be deemed to be engaged in predatory behavior-even if the resulting market price exceeds the dominant firm's average variable cost.

\subsection{Long Run}

Sustained production by dominant firms or successful entrants shall be deemed predatory if revenues are not fully cost recovering with respect to an appropriate assignment of all expenses incurred during the long-run interval.

Rule 1.1 is the basic rule. It does not disallow a conciliatory response, since accommodating output reductions are permitted. A conciliatory response is not mandated, however, except where the dominant firm is a high-cost supplier or the market-clearing price, were output to remain unchanged, would be less than the dominant firm's corresponding average variable costs. But the entering firm has no reason to anticipate that entry will be accommodated. To the contrary, the normal expectation is that such output as the entrant brings to the market will augment market supply in precisely that amount. Put differently, the dominant firm will not be expected to make a place for the new entrant by reducing its output in a partially or fully offsetting degree. The new entrant must thus be prepared to compete

123. The long-xun rule applies to dominant firms and successful entrants alike. As discussed at pp. 295-96 supra, 12 to 18 months would appear to be a sufficient period for the output rule to govern. 
with the dominant firm at a common post-entry price below the prevailing pre-entry price. Rule 1.2 applies to the longer run and permits output expansion provided that the resulting prices fully recover cost.

Rule 2.1 is the counterpart of rule 1.1. Areeda and Turner would permit output expansion in the immediate post-entry interval if the resulting market price exceeds the dominant firm's marginal (or average variable) cost. Rule 2.1 prohibits output expansion. The welfare losses attributable to rules that permit contingent expansions of output are thereby avoided. (Dominant firms have an incentive to price higher and supply on inefficient terms in the pre-entry period if a positive output reaction is permitted. Aggregate post-entry product is also supplied at a higher cost under Areeda-Turner rules.)

The proposed rules are also superior in relative ease of enforcement. The Areeda-Turner rule, which permits output expansion, crucially relies on a price-to-cost test, which is exceedingly difficult to apply. ${ }^{124}$ The proposed rule, by contrast, is much simpler: Any (demand adjusted) output increase by the dominant firm is deemed predatory. This is a much easier test statistic to develop. ${ }^{125}$

Rule 2.2 is concerned with behavior during the time period after the output restraint has expired. It makes allowance for the possibility that dominant firms (or successful entrants) with deep pockets will engage in long-term supply of a non-cost recovering kind in the hope of eliminating rivals. Since supply can be sustained efficiently only if infrastructure-renewing costs are incurred (maintenance, replacement of plant and equipment, labor training costs, etc.), these costs should be taken into account in judging whether product is being supplied on economical terms. If these expenses are not being covered in the long run, a presumption of unlawfulness is warranted.

No special rule of law is needed to cover the generational equipment case discussed in Part III. An entering firm should expect the dominant firm to sell its existing stock of equipment under the best

124. See R. Posner, supra note 3, at 190-91; Areeda \& Turner, supra note 3, at 716-18, 733; Cooper, supra note 3 , at 438.

125. The proposed short-run rule does include a variable cost proviso. A litigated case in which the dominant firm maintains or reduces output will thus require an examination of average variable costs. I would expect, however, that a major consequence of adopting the proposed rules would be a sharp drop in the number of litigated cases. Dominant firms will simply not respond aggressively to entry, and there is a presumption that nonresponse (holding output unchanged) is lawful. Except as market price falls drastically because of entry, the average variable cost floor is not apt to be breached (though this is more likely in highly labor-intensive industries). By contrast, dominant firms that increase output (as the Areeda-Turncr rules permit) in a region of increasing marginal (and variable) cost are more apt to occasion litigation. 
terms it can secure. If demand is inelastic the dominant firm may well retire equipment when new supplies appear, thereby making a place for the entrant. There should be no presumption, however, that this will occur. To the contrary, the normal expectation is that the dominant firm's entire stock will be marketed, in which case the new product brought onto the market by an entrant will increase market supplies by precisely the amount of the entrant's output.

Although these rules cover dominant firm reactive behavior, an additional rule of law is required to cover the case where a firm (large or small) is attempting to enter a new market.

3. With the exception of promotional terms offered for a very short duration in conjunction with the sale of nondurable consumer goods, a new entrant should be expected to offer product on terms that are cost recovering.

Rule 3 allows the new entrant greater latitude by permitting very low prices (even give-aways) for announcement purposes. The entrant can thus encourage customers to try the product on an experimental basis. This applies strictly to the short term. Part IV suggests some rough guidelines for assessing the allowable duration for a promotional campaign.

\section{B. Established firms ${ }^{\mathbf{1 2 6}}$}

\section{Lawful Behavior}

Occasional price wars of very limited duration do not pose predatory pricing threats to established oligopolists. Moreover, legal efforts to eliminate such behavior easily contribute to tighter oligopolistic pricing discipline. Accordingly, episodic price wars should be disregarded by the law. Attention should instead be focused exclusively on systematic pricing behavior among oligopolists.

\subsection{Intermediate Run}

(i) Normal: $\mathrm{P} \supseteq S R A C$ : Oligopolists charging prices that exceed short-run average costs shall be deemed to be behaving in a nonpredatory manner.

(ii) Excess Supply: $\mathrm{P} \supseteq A V C$ : Oligopolists may reduce prices to average variable cost levels under conditions of chronic excess supply (such as develop in a declining industry).

126. The rules set out here apply to the case described as "loose oligopoly" at pp. 321-23 supra. Promotional pricing by new entrants, see pp. $324-25$ supra, is covered by rule 3. The growth industry case poses special problems of its own. The pertinent considerations are set out at p. 320 supra. 


\subsection{Long Run}

Prices calculated to recover full costs over a sustained production interval during which plant renewal and related expenses are incurred will be deemed nonpredatory. ${ }^{127}$

\section{Unlawful Behavior}

Successive price wars, even though each is of very short duration, should be examined jointly rather than independently, in which case the intermediate-run test described below is relevant.

\subsection{Intermediate Run}

(i) Normal: $\mathrm{P}<S R A C$ : Sustained or frequently recurring pricing at less than short-run average costs will be deemed predatory. ${ }^{128}$

(ii) Excess Supply: $\mathrm{P}<A V C$ : Pricing at less than average variable costs will be deemed predatory, even under conditions of chronic excess supply.

\subsection{Long Run}

Sustained pricing that is not prospectively cost recovering will be deemed predatory.

Since $S R M C>S R A C>A V G$ when plant is operated beyond the minimum cost point, for the normal case these rules are more permissive than the $S R M C$ rules of Areeda and Turner, but are more restrictive than their average variable cost surrogate. This points up a fact which, though apparent on reflection, warrants comment: $A V G$ is often a poor surrogate for short-run marginal cost. Applying the $A V C$ rule to the normal case allows much more output expansion than the $S R M C$ rule it is meant to approximate. ${ }^{129}$ The proposed rules and the Areeda-Turner rules are identical only for the declining industry (excess supply) case.

\section{Fairness}

The term predatory pricing reeks with implications of unfairness. Curiously, however, the fairness aspect of predatory pricing rules has

127. Inasmuch as $S R A C$ is everywhere greater than or equal to $L R A C$, the long-run rule is redundant for the normal case. Lest the rules be misconstrued, however, the long run is included both here and in rule 2.2 for completeness.

128. Where plants are operating beyond design capacities this is a more permissive test for predatory behavior than a short-run marginal cost test.

129. As shown in the figure in note 122 supra, short-run marginal cost is equal to average variable cost at the output $Q_{x}$, but excecds average variable costs at outputs greater than $Q_{x}$. This deviation, moreover, becomes progressively greater as output is expanded. Average variable cost thus becomes a progressively less satisfactory surrogate for marginal cost as output is increaed above $\Omega_{0}$. 
received little attention in the recent literature. Partly this may be because fairness among oligopolists is difficult to characterize and the earlier literature complicated the task of characterization by failing to distinguish the new entry from the established rivalry cases. Partly it may be because fairness can be an obscure criterion..$^{130}$

Deriving an "optimal" predatory pricing rule based on notions of fairness poses formidable problems. A general criterion for assessing fairness is needed, but broad agreement on such a criterion is lacking. Although some might counsel that fairness be disregarded for this reason, a less ambitious option warrants consideration. Rather than derive the optimal rule, simply take the proposed rules as given and ask whether there are recognizable fairness differences between them. Comparative assessments of this kind are often feasible. ${ }^{131}$ Since attitudes about fairness are apt to be stronger when relations between new entrants and dominant firms are involved and since the analysis has been primarily concerned with predatory pricing in the context of new entry, these remarks on fairness will be restricted to the new entry condition. It will be useful to consider the three broad classes of rules that apply in the new entry case: the protectionist rule $(\mathrm{P}=\boldsymbol{P})$, the contingent supply rule $(\mathrm{P}=M C)$, and the business as usual rule $(Q=Q)$.

\section{A. Protectionist Rule}

The protectionist rule is that the dominant firm must take whatever actions are necessary to maintain market price when a new entrant appears. It involves a simple substitution of product supplied by the entrant for product previously supplied by the dominant firm. It violates a seemingly reasonable rule of industrial justice, namely, that entrants should expect to make their own way by offering incremental product in open markets.

130. As Professor Cooper notes, "[d]irect evidence of subjective motivations is always relevant in evaluating conduct, but inferences of motivation are ordinarily too dangerous to be accorded substantial weight." He observes that the courts have repeatedly refused to expand reliance on intent beyond this limited role, "instinctively recognizing that efforts to control the 'fairness' of competition must encounter immense difficulties." Cooper, supra note 3 , at 454 .

131. Note that the allocative efficiency advantage of the output restriction rule is a comparative one. Among the predatory pricing rules that have been proposed and are prospectively operational, it has the best properties. Some antitrust specialists will doubtlessly continue to favor "comprehensive appraisals" of the kind described by Scherer, see note 16 supra. The efficiency and fairness properties of such an approach are problematic and, I think, unascertainable. 


\section{B. Contingent Supply Rule}

Of the possible bases for judging fairness, equality of opportunity is an appealing criterion. Posner's test for predatory pricing, excluding "only a less efficient competitor,"132 would appear to qualify under this standard. But this test misses the dynamics of the problem. Product that could be supplied by an efficient dominant firm but is offered only for purposes of defeating entry in markets where entry appears and deterring entry elsewhere is surely not equivalent to product supplied on a regular basis. To the contrary, contingent supply of a gaming variety-now it's there, now it isn't, depending on whether an entrant has appeared or perished-has the earmarks of a punitive purpose, Simple open market offers of incremental product by new entrants are not feasible when confronted by strategic behavior of this kind. It seems reasonable to regard such actions as pernicious and to declare them unfair and inadmissible.

\section{Business as Usual}

The business as usual rule $(Q=Q)$ falls between the protectionist rule $(\mathrm{P}=P$, which implies $\mathrm{Q}<Q)$ and the contingent supply rule $(\mathrm{P}=M C$, which permits $\mathrm{Q}>\boldsymbol{Q})$ in severity. Under this rule the dominant firm is advised that it can supply as much or as little as it wants, but that it should be prepared to supply on a regular basis. If, as seems reasonable, dominant firms have been supplying product under conditions in which production, distribution, and marketing are in balance, a continuation of the dominant firm's supply is surely inoffensive. Indeed, to expect someone to unbalance his operations (due to indivisibilities), lay off experienced workers, and hold capacity idle is tantamount to assigning a handicap to the established firm. Although horse races may benefit from efforts to equalize chances, the general presumption is that achievement should not be penalized. Efforts to cripple one firm to benefit another are widely believed to be unfair.

I conclude that fairness and efficiency both favor the $Q=Q$ rule. Such harmony is perhaps not unusual; but neither is it always the case that what has the appearance of fairness and what contributes to efficiency warrant similar or identical behavior. It is nevertheless more satisfying when antitrust rules both yield consumer benefits (which is

132. R. POSNER, supra note 3 , at $\mathbf{1 9 3 .}$ 
what efficiency is mainly about) and do not conflict with norms of industrial justice. ${ }^{133}$

\section{Conclusion}

Predatory pricing rules must distinguish between meritorious claims and claims that discourage legitimate rivalry. ${ }^{134}$ Professors Areeda and Turner made a seminal contribution to the analysis of predatory pricing by establishing that systematic economic analysis can be applied to the thorny issues posed by predatory pricing. The straightforward application of "settled" microeconomic propositions to public policy can sometimes be hazardous, however. Caution is warranted where the assumptions on which received doctrine is based are greatly at variance with the real world circumstances under examination.

The specific issue that arises here is whether the allocative efficiency benefits associated with continuous marginal cost pricing likewise apply when such pricing is of a temporary, strategic kind. I submit that marginal cost pricing loses its appeal when it is applied contingently as a strategic deterrent to entry. The predatory pricing problem needs to be formulated in strategic terms in order for the effects of alternative pricing rules to be accurately displayed. Such an analysis reveals that, when compared to the output rule proposed by this article, the Areeda-Turner marginal cost rules result in losses of social welfare in the periods before and after entry.

The output rule also has efficiency properties superior to other cost-based rules and to umbrella pricing. It is no more difficult to comprehend and is easier to apply than alternative cost-based rules. Rudimentary considerations of fairness also favor the output restriction rule over both cost-based and umbrella pricing rules. The output restriction rule provides a practicable way to sort out meritorious from protectionist claims of predatory behavior.

133. Restraints on promotional pricing also have a fairness rationale. Thus although new entrant status may properly entitle a firm to a brief promotional interval during which cost-recovering rules may be suspended, to ask for more is to rig the rules of the game in favor of those who have deep pockets. This is patently unfair (and also inefficient) and should be disallowed.

134. Professor Scherer offers a similar summary of the objectives of predatory pricing law: "[t]he most workable competition in a [dominant firm industry] occurs when the dominant firm fears that it cannot deter entry from a high-price posture and is therefore led toward a continuing low-price, high-output strategy, recognizing inter alia that no rules will force it to make room if entry does occur." Scherer, Some Last Words on Predatory Pricing, 89 HaRv. L. REv. 901, 902 (1976). But while it is relatively easy to reach agreement that these are the purposes to be served, designing a set of rules that are not defective in pre-entry or post-entry respects is quite another matter. 


\section{The Yale Law Journal}

Volume 87, Number 2, December 1977

Peter J. Kalis

Editor-in-Chief

\author{
William N. Eskridge \\ Note \& Topics Editor \\ Matthew T. Heartney \\ Edward P. Krugman \\ Mark C. Rahdert \\ Note Editors
}

Richard H. Klapper

Managing Editor

David J. Grais

Charlotte G. Meriwether

David O. Stewart

Article is Book Review

Editors
Scott D. Baskin

Wendell R. Bird

Scott A. Boorman

David M. Brewer

Donald K. Cawley
James C. Francis IV

Edward E. Honnold

Daniel L. Koffsky

Michael D. Lowe

Margaret P.P. Mason
Mark L. Pelesh Bradley S. Phillips

Carl L. Reisner

David M. Skover

Emily G.H. Sullivan

Secretaries to the Editors M. Olive Butterfield, Pamela Willmott

\section{Student Contributors to This Issue}

Scott D. Baskin, Protective Orders Against the Press and the Inherent Powers of the Courts

David M. Brewer, SEC Rule 10b-16 and the Regulation of Margin Credit 